\title{
Modulation of Tumor Microenvironment through Aurea Helianthus Extract and Induced Exosomes
}

\author{
Yoonjin Park \\ Korea University \\ Kyunghwa Lee \\ Mitosbio \\ Suhng Wook Kim \\ Korea University \\ Min woo Lee \\ Korea University \\ Boyong Kim ( $\sim$ erythro74@korea.ac.kr) \\ Korea University \\ Seung Gwan Lee \\ Korea University
}

\section{Research Article}

Keywords: Endometrial cancer (EC), ovaries, fallopian tubes, cervix, blood, liver, bone

Posted Date: December 9th, 2020

DOl: https://doi.org/10.21203/rs.3.rs-116533/v1

License: (c) (i) This work is licensed under a Creative Commons Attribution 4.0 International License.

Read Full License 


\title{
Modulation of Tumor Microenvironment through Aurea helianthus Extract and Induced Exosomes
}

\author{
Yoonjin Park ${ }^{1,2,3, \#, \text { Kyunghwa Lee }}{ }^{4}$, Suhng Wook Kim, Min woo Lee ${ }^{1}$, Boyong Kim ${ }^{1,2,3,4, *}$, \\ Seung Gwan Lee ${ }^{1,2, *}$
}

${ }^{1}$ School of Health and Environmental Science, College of Health Science, Korea University, Korea

${ }^{2}$ Transdisciplinary Major in Learning Health Systems, Graduate School, Korea University

${ }^{3}$ Life Together, 13, Gongdan-ro, Chuncheon-si, Gangwon-do, Republic of Korea

${ }^{4}$ Mitosbio, 13, Gongdan-ro, Chuncheon-si, Gangwon-do, Republic of Korea

*Corresponding author; e-mail and phone: erythro74@korea.ac.kr,+82-10-9105-1435,

seunggwan@korea.ac.kr, +82-10-9913-0147

Keywords: Aurea helianthus, endometrial cancer, exosome, migration, microRNA, uterus 


\begin{abstract}
Endometrial cancer (EC) cells metastasize to various regions, including ovaries, fallopian tubes, cervix, blood, liver, bone, and brain. Various carcinogens cause EC. Exosomes are released from several types of cells and contain different components depending on cellular types. Although tocopherol- $\alpha$ and rutin were high components in Aurea helianthus, the Aurea helianthus extract was enormously useful in modulating tumor microenvironment contrasted to the two substances. Notably, we established that the extract induced bioactive exosomes in EC cells, and profiling of miRNAs in the extract inducing exosomes (EIE) present potency to develop a biological drug. The extract and EIE contributed to the following five biological categories for EC cells: (1) suppressed migration and invasion; (2) activated cellular senescence by attenuating mitochondrial membrane potential and enhancing autophagy; (3) attenuated reproductive cancer activity; (4) activated drug susceptibility; and (5) EIE contained miRNA associated with decreasing inflammation.
\end{abstract}

\title{
Introduction
}

Endometrial cancer (EC) is classified into two types; type I , the most common type, and II ${ }^{1}$. The cancer cells metastasize to various regions, including ovaries, fallopian tubes, cervix, blood, liver, bone, and brain 
2,3. EC is caused by multiple carcinogens, including chemicals, radiation, biological reasons as an imbalance of hormones, and human papillomavirus (HPV) ${ }^{4}$. Recently, EC in female cancers has been increased steadily, and notably, the incidence rate of type I EC has risen significantly globally ${ }^{1,5}$. Significant EC incidence causes are obesity, excessive estrogen, high blood pressure, and diabetes mellitus ${ }^{6}$.

The typical characteristics of activated cancer cells are evasion of cell death, healthy metabolism, limitless replication tissue invasion, and metastasis ${ }^{7}$. From many pieces of research, EC cells besides cervical cancer cells expressed specific markers including squamous cell carcinoma antigen (SCC), urinary gonadotropin fragment (UGF), Muc16 (CA-125; cancer antigen 125), cytokeratin 8 (CK8) 8, 9, 10,11. Metastasis is a significant characteristic of malignant tumors, and the character's prevention is an essential therapeutic point ${ }^{12}$. In metastasis' activation, cervical cancer cells are expressed several genes, including Homeobox (HOX) gene, PI3K/AKT/mTOR, epidermal growth factor receptor (EGFR), platelet-derived growth factor receptors (PDGFR), vascular endothelial growth factors (VEGF) besides vimentin 13,14,15, 16, 17 .

Exosomes, one of the extracellular vesicles, are released from several types of cells ${ }^{18}$. In particular, cancer cells release more exosomes containing different molecular compositions compared to normal cells. Tumorderived exosomes contribute to proliferation, inflammation, drug resistance, metastasis, tumorigenesis, and immune response ${ }^{18,19}$. Tumor-derived exosomes possess bioactive compounds including proteins, single-strand and genomic DNA, retrotransposon elements, messenger RNA, long noncoding RNA, and microRNAs (miRNAs) ${ }^{18,19}$. Exosomal miRNAs of tumor cells modulate the expression of oncogenes, activation of suppressors ${ }^{18}$. Likewise, alteration of exosomal miRNAs roles as a critical modulator for carcinogenesis, under a functional phytoextract, miRNAs in tumor cells is expected to be improved to alter tumor microenvironment.

Aurea helianthus belonging to the family Malvaceae serves various functions, including suppressing inflammation, fever, tumor, oxidation and melanogenesis, detoxification, modulation of lipid metabolism, and immune regulation ${ }^{20}$. Notably, the leaves have high tocopherol and rutin besides iron, vitamin $\mathrm{A}$, and 
vitamin $\mathrm{C}^{20}$. Tocopherol, the soluble phenolic, is a significant vitamin E structure and potent antioxidant and prevents cancer activity ${ }^{21}$. Additionally, rutin, known as the inhibitor against EGFR kinase, protects DNA structure and induced apoptosis of cancer cells by endoplasmic reticulum stress ${ }^{22}$. According to the reports ${ }^{20}, A$. helianthus extract protects human vaginal cells under oxidative and fungal stress and strongly suppresses an expression of CK8, Muc-16, and vimentin. Furthermore, the extract modulates the differentiation of monocytes and activation of phagocytosis against HPV peptides ${ }^{20}$.

This study has documented the effects of A. helianthus extract, $\alpha$-tocopherol, and rutin for suppression of cancer activity, including down-regulation of EC markers, suppression of invasion, and migration in EC cells. The functions of EIE by the extract were established by miRNAs' patterns and exposure to EC cells. This research will play a role as an essential key to developing a biological drug to protect or heal gynecological cancers. Especially since the results of the study suggest that the EIE robustly protect and attenuate against endometrial cancer, and miRNAs in EIE utilize to develop a synthesis of liposomes for a biological drug.

\section{Results}

This study's concept was to document the roles of the A. helianthus extract and EIE for modulation of tumor microenvironments in the five categories (Table 1). Furthermore, based on the miRNAs profiling in EIE, significant miRNAs for the categories were identified in EC cells (Fig 1.).

The extracts effectively down-regulated squamous cell carcinoma antigen (SCC) and urinary gonadotropin fragment (UGF) genes in the EC cells (Fig 2.). Contrasted to rutin, $25 \mathrm{ug} / \mathrm{mL}$ (R25), tocopherol- $\alpha, 5 \mathrm{ug} / \mathrm{mL}$ (TP5) and the extracts (100, 500, $1000 \mathrm{ug} / \mathrm{mL}$ ) effectively down-regulated SCC (Fig 2.). At $1000 \mathrm{ug} / \mathrm{mL}$, the SCC level was lower about two times than those of TP5 (Fig 2.). In UGF levels, the 
extracts $(100,500,1000 \mathrm{ug} / \mathrm{mL})$ down-regulated the levels, and notably, under the $1000 \mathrm{ug} / \mathrm{mL}$, the gene was down-regulated strongly in EC cells (Fig 2.).

Compared with the expression of the markers, all substances down-regulated the markers in EC cells (Fig 3.). In the CK8 levels, R25 down-regulated two times higher than those of TP5, and under all extracts, the levels were four times higher than those of TP5 (Fig 3.a, d). In Muc-16, although TP5 and R25 downregulated slightly, at AH $1000 \mathrm{ug} / \mathrm{mL}$, the level down-regulated strongly the level in EC cells (Fig 3. b, d). Unlike R25 down-regulated slightly, the vimentin levels, at TP5 and AH $1000 \mathrm{ug} / \mathrm{mL}$, were 1.28 and 5 times lower than those of R25, respectively (Fig 3.c, d).

Significantly, the extracts $(100,500,1000 \mathrm{ug} / \mathrm{mL})$ and TP5 inhibited the migration of EC (Fig 4a.). After the 36h, unlike the migrant activity of EC was enhanced firmly in control, the migration under TP5 and the extracts $(100,500,1000 \mathrm{ug} / \mathrm{mL})$ were inhibited intensely in the EC cells (Fig 4a.). Compared with the inhibitory areas among all conditions, at $\mathrm{AH} 1000 \mathrm{ug} / \mathrm{mL}$, the value was seven times higher than the control, and at $\mathrm{AH} 100,500 \mathrm{ug} / \mathrm{mL}$, the values were about two times higher than those of TP5. Likewise, the vimentin result and the value in R25 were not different from those of the control (Fig 3d and Fig 4a.). Interestingly, at only one dose, $\mathrm{AH} 1000 \mathrm{ug} / \mathrm{mL}$, EC cells' invasive activity was suppressed strongly, and the activity is 1.56 times higher than those of the control (Fig $4 \mathrm{~b}$.).

In considering metabolic modulation, the substances affected mitochondrial membrane potential (MMP) and cellular senescence. Without TP5, although R25 attenuated MMP at 1.5 times lower than in control, the inactive intensities of AH 500 and 1000 were more strongly lower than R25. (Fig 5a.). The senescence of the cancer cells was activated strongly at all substances. Notably, the activity at AH $1000 \mathrm{ug} / \mathrm{mL}$ was about 3.45 and 2.1 times higher than those of TP5 and R25, respectively (Fig 5b.).

Under the three bioactive substances, the induced exosomes were isolated from EC cells (Fig 6a.). The EC cells were exposed to the exosomes down-regulated the markers, including SCC, UGF, and IL2-receptor 
(Fig 6b). Additionally, EIE down-regulated drug-resistant associated genes, including NF- $K B$ (P50, P52),

mTORC2, and ABCB1 (Fig 6c.). Furthermore, the exosomes by the extract and TP down-regulated Muc16+vimentin+ cells count at 0.37 and 0.45 times, respectively (Fig 6d). The clustering heatmap displayed patterns of significantly altered miRNAs based on analytic results for miRNAs in the induced exosomes by three substances (Fig 7a). Unlike the heatmap pattern by rutin, the heatmap was dramatically altered at AH1000 (Fig 7a). Moreover, the miRNA distribution between AH1000 and control on the scatter plot was the most different, wherein 112 and 102 miRNAs in EIE were up and down-regulated in EC cells (Fig 7b, c). Although some miRNAs by rutin were altered in various categories, the miRNAs in the categories were down-regulated at AH1000 and TP5 (Fig 7d). Several miRNAs associated with five biochemical categories were dramatically altered in EIE (Fig 8 and Table 2). Based on the results (Fig 8 and Table 2), EIE modulated specific bioactivities, including autophagy, drug transporting and carbolic process, cell migration, endocrinal metabolism, cellular respiration, and immune response. Notably, the level of hsa-miR-423-5p and hsa-miR-1908-5p were 100 times lower than those of control (Figure 8, Table2). Moreover, the dramatic alteration of miRNAs was involved in several categories (Fig 8 and Table 2).

\section{Discussion}

EC is the most popular malignancy in gynecological cancers, and the malignant tumor is associated with obesity ${ }^{23}$. The excess of estrogen causes EC, insulin resistance, and inflammation-driven by obesity, and the incidence rate of EC has been increasing in parallel with obesity ${ }^{24}$. This study documented the suppression of cancer activity by three substances to compare the relative efficacy of the extract and functional alteration of the induced exosomes in EC cells. Compared to tocopherol- $\alpha$ and rutin, the extract contained two significant characteristics. One is to suppress various cancer activities, including cancerous metabolism, migration, and invasiveness. Another is to induce a substantial alteration of miRNAs in EIE (Fig 1.). Unlike tocopherol- $\alpha$ and rutin, the extracts significantly down-regulated SCC and UGF, 
particularly at AH1000 (Fig 2.). SCC bind to carbonyl reductase, which inhibits malignant behavior and TGF- $\beta$ signaling in uterine cancer cells ${ }^{25}$.

Additionally, SCC inhibits cellular apoptosis cells by irradiation, natural killer cells, an anticancer drug, irradiation, and promoting migration and invasion by decreasing E-cadherin ${ }^{26,27,28}$. UGF is known as the $\beta$-subunit of human chorionic gonadotropin (hCG $\beta$ ), which also suppresses cellular apoptosis ${ }^{29}$ and promotes migration, invasion, malignant transformation, and drug resistance ${ }^{30,31,32}$. These results suggest that the AH1000 effectively suppressed EC cells' malignant behaviors, and the extract plays good material for preventing malignant behavior and cancerous transformation of normal endometrial cells. These predicted functions were shown by the results in biological categories, including migration, invasion, and expression of malignant markers, cellular senescence, and mitochondrial membrane potential (Fig2-5.).

The extract and EIE modulate tumor microenvironments around EC cells through their effects on the biological five categories.

First, in migration and invasion, tocopherol- $\alpha$ and the extracts significantly inhibited the EC cells' malignant behaviors (Fig3.) In particular, the induced exosomes by AH1000 contained the inhibitory migration miRNAs such as hsa-miR-1908-5p and hsa-miR-20b-5p. Interestingly their levels were 100 times and 8.2 times higher than those of the control (Table 2 and Fig 7, 8.). Target genes of hsa-miR-1908-5p and hsa-miR-20b-5p are prostaglandin endoperoxide synthase 2 (PTGS2) and vascular endothelial growth factor A (VEGFA), respectively. The PTGS2 protein level is modulated by beta-2 adrenergic receptor (ADRB2) receptor signaling, and silencing PTGS2 suppresses migration and invasion of ovarian cancer cells ${ }^{33}$. VEGF protein is associated with critical roles, including migration, invasion, angiogenesis, endothelial cell proliferation, invasion, and migration of cancer cells ${ }^{34}$. Under EIE (Fig. 6), malignant markers, including SCC, UGF, interleukin-2 receptor (IL-2), Muc-16, and vimentin, were more strongly down-regulated in EC cells. These results showed that the two miRNAs in the induced exosome strongly suppress migration and invasion of the exosomes' peripheral EC cells.

Second, in cellular senescence, the three substances activated the senescence in EC cells, and the senescence was intensely triggered under AH1000 (Fig. 5). Based on miRNAs profiling in the induced exosomes, specific miRNAs such as autophagy suppression and DNA repair were up-regulated under AH1000 (Table 1). Interestingly, anti-Unc-51-like kinase 1 (ULK1) ${ }^{35}$, hsa-miR-423-5p was down-regulated 100 times, and several anti-DNA repair genes hsa-miR-93-3p (Table 1) were up-regulated 8.1 times. The 
exosomal results corresponded with the senescence results (Fig. 5), and the extract activated cellular senescence through activation of cytotoxic autophagy and suppression of DNA repair. Further, the induced exosomes contained potency for cellular senescence acceleration through suppression of DNA repair in EC cells. As described in this study (Table 1), hsa-miR-615-3p and hsa-let-7e-5p were up-regulated in the induced exosomes. The miRNAs targeted several proteins associated with DNA repair.

Regarding activity for mitochondrial membrane potential, at AH 500 and 1000, the activity significantly decreased, and the value was 2.92 times lower than in control at AH 1000. With the exosomal results, antiATP5A1 and ATP5I hsa-miR-877-3p were up-regulated at 6.7 times (Table 1). Documented researches ${ }^{36,37}$, ATP5A1, ATP5I genes activate ATP synthesis on the electron transporting system in mitochondria. Although cancerous activity is based on ATP synthesis activation, the extract suppresses ATP synthesis by inhibiting mitochondrial membrane activity.

Third, in reproductive cancer activity, miRNAs in EIE affect endocrinal modulation, such as estrogen and prostaglandin synthesis and signaling. Anti-HSD17B12 hsa-miR-874-3p was significantly downregulated but anti-STRN3 hsa-miR-125b-5p, anti-PHB2 hsa-miR-10a-5p and anti-ISL1 hsa-let-7d-5p were significantly down-regulated in EIE (Table 1 and Fig. 8). Unlike HSD17B12 protein, estradiol synthesis enzyme 38 , STRN3, PHB2, and ISL1 are associated with negative regulation of estrogenic intracellular signaling 39, 40, 41. Likewise, excess of estrogen drives several diseases, including diabetes mellitus and gynecological cancers; these endocrinal modulations mean that EIE prevents carcinogenesis and cancer deterioration by the hormones. Furthermore, PTGS2 targeting hsa-miR-1908-5p was strongly increased in EIE. Prostaglandin-endoperoxide synthase 2 (PTGS2) protein known as cyclooxygenase-2 (COX-2) synthesizes prostaglandin from arachidonic acid; the synthesized prostaglandin contributes to tumorigenesis including proliferation, metastasis, angiogenesis ${ }^{42}$. The dramatic increase of hsa-miR-1908$5 p$ in EIE means a strong suppression of tumorigenesis by attenuated COX-2 in peripheral EC cells.

Fourth, the extract and EIE were involved in attenuating drug resistance and autophagy in EC cells. Under the extract, ha-miR-451a targeting $A B C B 1$ was increased in the induced exosomes. When exposed to an anti-cancer drug, cancer cells alter their phenotypes to resist the drug by increasing ATP binding cassette subfamily B member 1 (ABCB1) protein ${ }^{43}$. Furthermore, the expression of ABCB1 is modulated by various transcription factors, including $\mathrm{P}^{4} 3^{44}, \mathrm{NF}-\mathrm{KB}^{45}$, and $\mathrm{YB}-1^{46}$. Contrasted to the alteration of hsa-miR451, hsa-miR-423-5p, hsa-miR-19b-3p, hsa-miR-320a in EIE were dramatically decreased, and notably, hsa- 
miR-423-5p was 100 times lower than those of the control. Interestingly, corresponded to the results for miRNA profiling (Table 2), EIE down-regulated drug-resistant genes, including NF-KB (P50, P52), mTORC2, and $A B C B 1$ (Fig 6c.). Activated NF-KB (P50, P52) and mTORC2 induce multidrug resistance ${ }^{47}{ }^{48}$ and suppression of autophagy ${ }^{49,50}$. These results documented that EIE intensely causes enhancing of autophagy and attenuation of drug resistance in around EC cells.

Fifth, the down-regulated hsa-let-7e-5p contributed to suppressing innate immune response by upregulation of POLR3D protein, a subunit of RNA polymerase ${ }^{51}$. POLR3D activates interferon- $\beta$ (IFN- $\beta$ ) production associated with the down-regulation of inflammatory responses ${ }^{52}$. In correspondence with the described research ${ }^{20}$, the extract attenuates inflammatory response through EIE from EC cells.

Consequently, Aurea Helianthus extract intensely contributed to the modulation of tumorigenic microenvironments in EC cells. Although $\alpha$-tocopherol and rutin were high components in Aurea helianthus ${ }^{20}$, the extract effectively modulated the environment than the two substances. The extract's modulations were summarized in five biological categories: suppression of migration and invasion, increasing drug susceptibility, decreasing inflammation, attenuation of reproductive cancer activity, and activation of cellular senescence. The induced exosome effects suggest a biological cancer drug's potency to protect and heal gynecological cancers.

\section{Materials and methods}

\section{- Cell culture}

Human endometrial cancer cells (ATCC HTB115, VA, USA) were purchased and cultured in Dulbecco's Modified Eagle Medium (Gibco, Massachusetts, USA) containing high glucose. After ripening at $10{ }^{\circ} \mathrm{C}$ for $48 \mathrm{~h}$, the flower of A. helianthus was exposed to infrared ray for $2 \mathrm{~h}$ and ground (400 mesh). The powder was extracted and concentrated under $0.08 \mathrm{MPa}, 70{ }^{\circ} \mathrm{C}$ for $2 \mathrm{~h}$, and filtered with a $0.2 \mu \mathrm{m}$ syringe filter (Nalgene, Massachusetts, USA). After treating of dosages; the extracts ( 100, 500, $1000 \mu \mathrm{g} / \mathrm{mL}$ ) supported by Life Together (Gangwon-Do, Korea), tocopherol (Sigma, MO, USA) $5 \mu \mathrm{g}$ and rutin (Sigma) 25ug, the endometrial cancer cells were cultured for $72 \mathrm{~h}$ at $37^{\circ} \mathrm{C}$, under $5 \% \mathrm{CO} 2$. 


\section{- Quantitative PCR}

Total RNA in cells exposed to the three substances were isolated using the RiboEx reagent (GeneAll, Se oul, Korea). After synthesizing cDNA using Maxime RT PreMix (iNtRON, Seongnam, Korea), quantitativ e PCR was performed with primers (Table 1 ) at the cycling parameters: $1 \mathrm{~min}$ at $95^{\circ} \mathrm{C}$, followed by $35 \mathrm{cycl}$ es of $35 \mathrm{~s}$ at $59^{\circ} \mathrm{C}$ and $1 \mathrm{~min}$ at $72^{\circ} \mathrm{C}$ for 35 cycles.

\section{- Flow-cytometry analysis}

To analyze the markers' expression levels, including CK8, Muc-16, and vimentin, all types of cells fixed with $2 \%$ paraformaldehyde for $24 \mathrm{~h}$ were treated with $0.02 \%$ Tween 20 for $5 \mathrm{~min}$. The fluorescence leveled three immunoglobulins, FITC anti-cytokeratin 8 (Abcam, Cambridge, UK), PE-anti-CA125 (Santacruz, CA, USA), and APC-anti-vimentin (Santacruz) were treated to the cells for $48 \mathrm{~h}$ in room temperature, $85 \mathrm{rpm}$ agitating. The washed samples were analyzed using a flow cytometer (BD FACScalibur) and FlowJo 10.6.1 (BD science).

\section{- Migration test}

In estimating the three substances' inhibitory efficacy for migration, EC cells were cultured in the Radius $^{\mathrm{TM}}$ 24-well cell migration assay kit (CELL BIOLABS, INC. San Diego, CA, USA) under the substances. The migration was estimated with time intervals $(0,12,24,36,48,60 \mathrm{hrs})$ using Nikon ECLIPSE Ts2 (Tokyo, Japan) and imaging software Nikon NIS Elements V5.11.

\section{- Invasiveness test}

In estimating the three substances' inhibitory efficacy for invasiveness, EC cells were culture in CytoSelect $^{\mathrm{TM}}$ 24-well cell invasion assay kit (CELL BIOLABS, INC. San Diego, CA, USA) under the 
substances. The invasiveness was estimated using a flow cytometer (BD FACScalibur) and FlowJo 10.6.1

(BD science).

\section{- Mitochondrial membrane potential test}

After exposed to the three substances for three days, EC cells were stained with JC-1 Mitochondrial Membrane Potential Assay Kit (Invitrogen, MA, USA), and mitochondrial activity was estimated using a flow cytometer (BD FACScalibur) and FlowJo 10.6.1 (BD science).

\section{- Senescence test}

After exposure to the three substances during three days, EC cells were stained with CellEvent ${ }^{\mathrm{TM}}$ Senescence Green Flow Cytometry Assay Kit (Invitrogen, MA, USA). The stained cells were measured using a flow cytometer (BD FACScalibur) and FlowJo 10.6.1 (BD science).

\section{- Exosome purification and microRNA profiling}

The semi-confluent EC cells were cultured for three days under the substances without FBS. Their supernatants were collected, and the induced exosomes in the supernatants were isolated using the exoEasy Maxi kit (QIAGEN, Venlo, Netherlands). The induced exosomes from the sample size (n=3) were summated for their miRNAs profiling under each substance. Small microRNAs were sequenced by ebiogen Inc (Seoul, Korea) to analyze exosomal functions. Agilent 2100 bio-analyzer and the RNA 6000 PicoChip (Agilent Technologies, Amstelveen, The Netherlands) were used to assess RNA quality. RNA quantification was assessed using a NanoDrop 2000 Spectrophotometer system (ThermoFisher Scientific, Waltham, MA, USA). The Agilent 2100 Bio-analyzer instrument for the High-sensitivity DNA Assay (Agilent Technologies, Inc., USA) to prepare and sequence small RNA libraries, and NextSeq500 system 
single-end 75 sequencings (Illumina, San Diego, CA., USA) were used for them. In obtaining a bam file (alignment file), the sequences were mapped by bowtie2 software, and read counts were extracted from the alignment file using bedtools (v2.25.0) and R language (version 3.2.2) to determine the expression level of miRNAs. miRWalk 2.0 was used for miRNA target study, and ExDEGA v.2.0 was used to deduce various results, including van diagram, heat map, scattering plots, and bar graphs.

\section{- Statistical analysis}

All experiments were performed thrice $(\mathrm{n}=3)$, and the data were analyzed by paired T-test and analysis of variance (ANOVA), using the SPSS software v26 (IBM, NY, USA).

\section{- Data availability}

The datasets generated and/or analyzed during the current study might be availed from the corresponding authors, on reasonable request. 


\section{References}

1. Berstein LM, Berlev IV, Baltrukova AN. Endometrial cancer evolution: new molecular-biologic types and hormonal-metabolic shifts. Future Oncol 13, 2593-2605 (2017).

2. Bharambe BM, Deshpande KA, Surase SG, Ajmera AP. Malignant transformation of leiomyoma of the uterus to leiomyosarcoma with metastasis to the ovary. J Obstet Gynaecol India 64, 68-69 (2014).

3. Piura E, Piura B. Brain metastases from endometrial carcinoma. ISRN Oncol 2012, 581749 (2012).

4. Giatromanolaki A, Sivridis E, Papazoglou D, Koukourakis MI, Maltezos E. Human papillomavirus in endometrial adenocarcinomas: infectious agent or a mere "passenger"? Infect Dis Obstet Gynecol 2007, 60549 (2007).

5. Evans T, Sany O, Pearmain P, Ganesan R, Blann A, Sundar S. Differential trends in the rising incidence of endometrial cancer by type: data from a UK population-based registry from 1994 to 2006. Br J Cancer 104, 1505-1510 (2011).

6. Loomis D, Huang W, Chen G. The International Agency for Research on Cancer (IARC) evaluation of outdoor air pollution's carcinogenicity: focus on China. Chin J Cancer 33, 189-196 (2014).

7. Hanahan D, Weinberg RA. The hallmarks of cancer. Cell 100, 57-70 (2000).

8. Meier W, Eiermann W, Stieber P, Schneider A, Fateh-Moghadam A, Hepp H. Experiences with SCC antigen, a new tumor marker for cervical carcinoma. Eur J Cancer Clin Oncol 25, 1555-1559 (1989).

9. Gilles $\mathrm{C}$, et al. Vimentin expression in cervical carcinomas: association with invasive and migratory potential. J Pathol 180, 175-180 (1996).

10. Shen H, Guo M, Wang L, Cui X. MUC16 facilitates cervical cancer progression via JAK2/STAT3 phosphorylation-mediated cyclooxygenase-2 expression. Genes Genomics 42, 127-133 (2020).

11. Nam JH, Chang KC, Chambers JT, Schwartz PE, Cole LA. Urinary gonadotropin fragment, a new tumor marker. III. Use in cervical and vulvar cancers. Gynecol Oncol 38, 66-70 (1990).

12. Steeg PS, Theodorescu D. Metastasis: a therapeutic target for cancer. Nat Clin Pract Oncol 5, 206-219 (2008).

13. Lopez-Romero R, et al. [The role of developmental HOX genes in cervical cancer]. Rev Med Inst Mex 
Seguro Soc 53 Suppl 2, S188-193 (2015).

14. Bai X, Ma Y, Zhang G. Butein suppresses cervical cancer growth through the PI3K/AKT/mTOR pathway. Oncol Rep 33, 3085-3092 (2015).

15. $\mathrm{Hu} \mathrm{YF}$, et al. Expressions and clinical significance of autophagy-related markers Beclin1, LC3, and EGFR in human cervical squamous cell carcinoma. Onco Targets Ther 8, 2243-2249 (2015).

16. Cheng Y, Ma D, Zhang Y, Li Z, Geng L. Cervical squamous cancer mRNA profiles reveal the key genes of metastasis and invasion. Eur J Gynaecol Oncol 36, 309-317 (2015).

17. Biedka M, Makarewicz R, Marszalek A, Sir J, Kardymowicz H, Goralewska A. Labeling of microvessel density, lymphatic vessel density and the potential role of proangiogenic and lymphangiogenic factors as a predictive/prognostic factors after radiotherapy in patients with cervical cancer. Eur J Gynaecol Oncol 33, 399-405 (2012).

18. Zhang C, Ji Q, Yang Y, Li Q, Wang Z. Exosome: Function and Role in Cancer Metastasis and Drug Resistance. Technol Cancer Res Treat 17, 1533033818763450 (2018).

19. Thery C, Zitvogel L, Amigorena S. Exosomes: composition, biogenesis, and function. Nat Rev Immunol 2, 569-579 (2002).

20. Park $Y$, et al. Protection and immune modulation of activated human vaginal epithelial cells by Aurea helianthus extract. Sci Rep 10, 9227 (2020).

21. Das Gupta S, Suh N. Tocopherols in cancer: An update. Mol Nutr Food Res 60, 1354-1363 (2016).

22. Perk AA, et al. Rutin mediated targeting of signaling machinery in cancer cells. Cancer Cell Int 14, 124 (2014).

23. Washington CR, Haggerty A, Ronner W, Neff PM, Ko EM. Knowledge of endometrial cancer risk factors in a general gynecologic population. Gynecol Oncol 158, 137-142 (2020).

24. Njoku K, Abiola J, Russell J, Crosbie EJ. Endometrial cancer prevention in high-risk women. Best Pract Res Clin Obstet Gynaecol 65, 66-78 (2020).

25. Kajimura $\mathrm{T}$ et al. Overexpression of carbonyl reductase 1 inhibits malignant behaviors and epithelial mesenchymal transition by suppressing TGF-beta signaling in uterine leiomyosarcoma cells. Oncol Lett 18, 1503-1512 (2019). 
26. Suminami Y, Nagashima S, Vujanovic NL, Hirabayashi K, Kato H, Whiteside TL. Inhibition of apoptosis in human tumor cells by the tumor-associated serpin, SCC antigen-1. Brit J Cancer 82, 981-989 (2000).

27. Murakami A, Suminami Y, Hirakawa H, Nawata S, Numa F, Kato H. Squamous cell carcinoma antigen suppresses radiation-induced cell death. Br J Cancer 84, 851-858 (2001).

28. Murakami A, et al. Suppression of SCC antigen promotes cancer cell invasion and migration through decreased E-cadherin expression. Int J Oncol 29, 1231-1235 (2006).

29. Jankowska A, et al. Reduction of human chorionic gonadotropin beta subunit expression by modified U1 snRNA caused apoptosis in cervical cancer cells. Molecular Cancer 7, 26 (2008).

30. Wu W, et al. $\beta$-hCG promotes epithelial ovarian cancer metastasis through ERK/MMP2 signaling pathway. Cell Cycle 18, 46-59 (2019).

31. Singh P, Sarkar M, Agrawal U, Huhtaniemi I, Pal R. The transgenic expression of the $\beta$-subunit of human chorionic gonadotropin influences the growth of implanted tumor cells. Oncotarget 9, 34670, (2018).

32. Berman R, Steel G. Induced and inherent resistance to alkylating agents in human small-cell bronchial carcinoma xenografts. Brit J Cancer 49, 431-436 (1984).

33. Nagaraja AS, et al. Sustained adrenergic signaling leads to increased metastasis in ovarian cancer via increased PGE2 synthesis. Oncogene 35, 2390-2397 (2016).

34. Morelli MP, et al. Targeting vascular endothelial growth factor receptor-1 and -3 with cediranib (AZD2171): effects on migration and invasion of gastrointestinal cancer cell lines. Mol Cancer Ther 8, 2546-2558 (2009).

35. Mu P, Karuppasamy R. Discovery of human autophagy initiation kinase ULK1 inhibitors by multidirectional in silico screening strategies. J Recept Signal Transduct Res 39, 122-133 (2019).

36. Xu G, Li JY. ATP5A1 and ATP5B are highly expressed in glioblastoma tumor cells and endothelial cells of microvascular proliferation. Journal of neuro-oncology 126, 405-413 (2016).

37. Brüggemann $\mathrm{M}$, et al. Systematic analysis of the mitochondrial ATP Synthase (Complex V) subunits in clear cell renal cell carcinoma. Translational oncology 10, 661-668 (2017). 
38. Kemiläinen $\mathrm{H}$, et al. The hydroxysteroid (17ß) dehydrogenase family gene HSD17B12 is involved in the prostaglandin synthesis pathway, the ovarian function, and regulation of fertility. Endocrinology 157, 3719-3730 (2016).

39. Tan B, Long X, Nakshatri H, Nephew KP, Bigsby RM. Striatin-3 $\gamma$ inhibits estrogen receptor activity by recruiting a protein phosphatase. Journal of molecular endocrinology 40, 199-210 (2008).

40. Kim J-W, et al. Activation of an estrogen/estrogen receptor signaling by BIG3 through its inhibitory effect on nuclear transport of PHB2/REA in breast cancer. Nature Precedings, 1-1 (2009).

41. Gay Fdr, Anglade I, Gong Z, Salbert G. The LIM/Homeodomain Protein Islet-1 Modulates Estrogen Receptor Functions. Molecular Endocrinology 14, 1627-1648 (2000).

42. Young JL, Jazaeri AA, Darus CJ, Modesitt SC. Cyclooxygenase-2 in cervical neoplasia: A review. Gynecologic Oncology 109, 140-145 (2008).

43. Wagner W, Kania KD, Blauz A, Ciszewski WM. The lactate receptor (HCAR1/GPR81) contributes to doxorubicin chemoresistance via $\mathrm{ABCB} 1$ transporter up-regulation in human cervical cancer HeLa cells. J Physiol Pharmacol 68, 555-564 (2017).

44. Goldsmith ME, Gudas JM, Schneider E, Cowan KH. Wild type p53 stimulates expression from the human multidrug resistance promoter in a p53-negative cell line. J Biol Chem 270, 1894-1898 (1995).

45. Zhou G, Kuo MT. NF-kappaB-mediated induction of mdr1b expression by insulin in rat hepatoma cells. J Biol Chem 272, 15174-15183 (1997).

46. Bargou RC et al. Nuclear localization and increased transcription factor YB-1 in primary human breast cancers are associated with intrinsic MDR1 gene expression. Nat Med 3, 447-450 (1997).

47. Salvatore C, Camarda G, Maggi CA, Goso C, Manzini S, Binaschi M. NF-кB activation contributes to anthracycline resistance pathway in human ovarian carcinoma cell line A2780. International journal of oncology 27, 799-806 (2005).

48. Butt G, et al. Role of mTORC1 and mTORC2 in Breast Cancer: Therapeutic Targeting of mTOR and Its Partners to Overcome Metastasis and Drug Resistance. In: Breast Cancer Metastasis and Drug Resistance). Springer (2019).

49. Papademetrio DL, et al. Inhibition of survival pathways MAPK and NF-kB trigger apoptosis in pancreatic ductal adenocarcinoma cells via suppression of autophagy. Targeted oncology 11, 183-195 
(2016).

50. Vakana E, Sassano A, Platanias LC. Induction of autophagy by dual mTORC1-mTORC2 inhibition in BCR-ABL-expressing leukemic cells. Autophagy 6, 966-967 (2010).

51. Chiu Y-H, MacMillan JB, Chen ZJ. RNA Polymerase III Detects Cytosolic DNA and Induces Type I Interferons through the RIG-I Pathway. Cell 138, 576-591 (2009).

52. Hahn AF, Hartung H-P, Dyck PJ. Chapter 99 - Chronic Inflammatory Demyelinating Polyradiculoneuropathy. In: Peripheral Neuropathy (Fourth Edition) (eds Dyck PJ, Thomas PK). W.B. Saunders (2005).

\section{Acknowledgments}

Life Together and Korea University supported this study. We would like to thank Editage (www.editage.co.kr) for English language editing.

\section{Author contributions}

Boyong Kim and Yoonjin Park: conceived this study and designed the experiments. Boyong Kim and Seung Gwan Lee: conducted the experiments. Kyunghwa Lee, Suhng Wook Kim, and Min woo Lee: analyzed the results.

\section{Competing interests}

The authors declare no competing interests. 
Table 1. List of primers for quantitative PCR

\begin{tabular}{|c|c|c|}
\hline Gene & & Primer Sequence \\
\hline \multirow{2}{*}{$\begin{array}{c}\text { SCC } \\
\text { (squamous cell carcinoma antigen) }\end{array}$} & $\mathrm{F}$ & ACACTGGTTCTTGTGAACGC \\
\hline & $\mathrm{R}$ & GCCTGTACATCCTTGTTTGGC \\
\hline \multirow{2}{*}{$\begin{array}{c}\text { UGF } \\
\text { (urinary gonadotropin fragment) }\end{array}$} & $\mathrm{F}$ & ATGTGCGCTTCGAGTCCATC \\
\hline & $\mathrm{R}$ & AGAAAGACCCGCCAGAGTGC \\
\hline \multirow{2}{*}{$\begin{array}{c}\text { Il-2 receptor } \\
\text { (interleukin-2 receptor) }\end{array}$} & $\mathrm{F}$ & CAGTTCGCCGCATCCTTCT \\
\hline & $\mathrm{R}$ & TAAGTATTGGGCTGGCGTGT \\
\hline \multirow{2}{*}{ mTORC2 } & $\mathrm{F}$ & AGTACGAGGGCGGAATGACA \\
\hline & $\mathrm{R}$ & GCCACCACCTCTGGATTCTG \\
\hline \multirow{2}{*}{ NF-кB(P50) } & $\mathrm{F}$ & CGGAGCCCTCTTTCACAGTT \\
\hline & $\mathrm{R}$ & TTCAGCTTAGGAGCGAAGGC \\
\hline \multirow{2}{*}{ NF-кB(P52) } & $\mathrm{F}$ & AGGTGCTGTAGCGGGATTTC \\
\hline & $\mathrm{R}$ & AGCGGCACTGTATAGGGCAGA \\
\hline \multirow{2}{*}{ ABCB1 } & $\mathrm{F}$ & TCTTGTCCAAACTGCCTGTGA \\
\hline & $\mathrm{R}$ & TAATTGTGCCTCACCCCACC \\
\hline \multirow{2}{*}{ GAPDH } & $\mathrm{F}$ & AGTCTGTTATAACCCAGACGAG \\
\hline & $\mathrm{R}$ & GCATCACAACCAATAGGTGTGA \\
\hline
\end{tabular}


Table 2. List of significant alteration of miRNAs in the induced exosomes by the extract and their targeted genes

\begin{tabular}{|c|c|c|c|c|}
\hline \multicolumn{2}{|r|}{ Target gene Category } & \multirow{2}{*}{$\begin{array}{c}\text { miRNA } \\
\text { Symbol } \\
\text { hsa-miR-1908-5p }\end{array}$} & \multirow{2}{*}{$\begin{array}{c}\text { Fold } \\
\text { Change } \\
100\end{array}$} & \multirow{2}{*}{$\begin{array}{c}\text { Target Gene } \\
\text { PTGS2 }\end{array}$} \\
\hline & & & & \\
\hline & 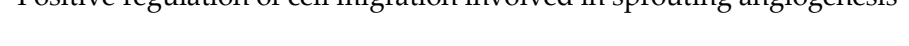 & hsa-miR-20b-5p & 8.2 & VEGFA \\
\hline \multirow{7}{*}{ II } & \multirow{3}{*}{ Positive regulation of autophagy } & hsa-miR-423-5p & 100 & ULK1 \\
\hline & & hsa-miR-19b-3p & 25 & PRKAA1 \\
\hline & & hsa-miR-320a & 20 & ULK1 \\
\hline & \multirow{3}{*}{ Positive regulation of DNA repair } & hsa-miR-93-3p & 8.1 & $\begin{array}{c}\text { NPM1, OTUB1, } \\
\text { PARP1, SMC1A, } \\
\text { TRIM28 }\end{array}$ \\
\hline & & hsa-miR-877-3p & 6.7 & $\begin{array}{c}\text { SUPT16H, } \\
\text { TRIM28 }\end{array}$ \\
\hline & & & & HMGB1 \\
\hline & Mitochondrial ATP synthesis coupled proton transport & hsa-miR-877-3p & 6.7 & ATP5A1, ATP5I \\
\hline \multirow{5}{*}{ III } & Estrogen biosynthetic process & hsa-miR-874-3p & 7.2 & HSD17B12 \\
\hline & \multirow{3}{*}{ Negative regulation of intracellular estrogen receptor signaling pathway } & hsa-miR-125b-5p & 10 & STRN3 \\
\hline & & hsa-miR-10a-5p & 6.9 & PHB2 \\
\hline & & hsa-let-7d-5p & 6.8 & ISL1 \\
\hline & Positive regulation of prostaglandin biosynthetic process & hsa-miR-1908-5p & 100 & PTGS2 \\
\hline IV & Drug transmembrane transport & hsa-miR-451a & 4 & ABCB1 \\
\hline $\mathrm{V}$ & Regulation of innate immune response & hsa-let-7e-5p & 12.5 & POLR3D \\
\hline
\end{tabular}

\footnotetext{
Up-Regulation

Down-Regulation
} 


\section{Figure Legends}

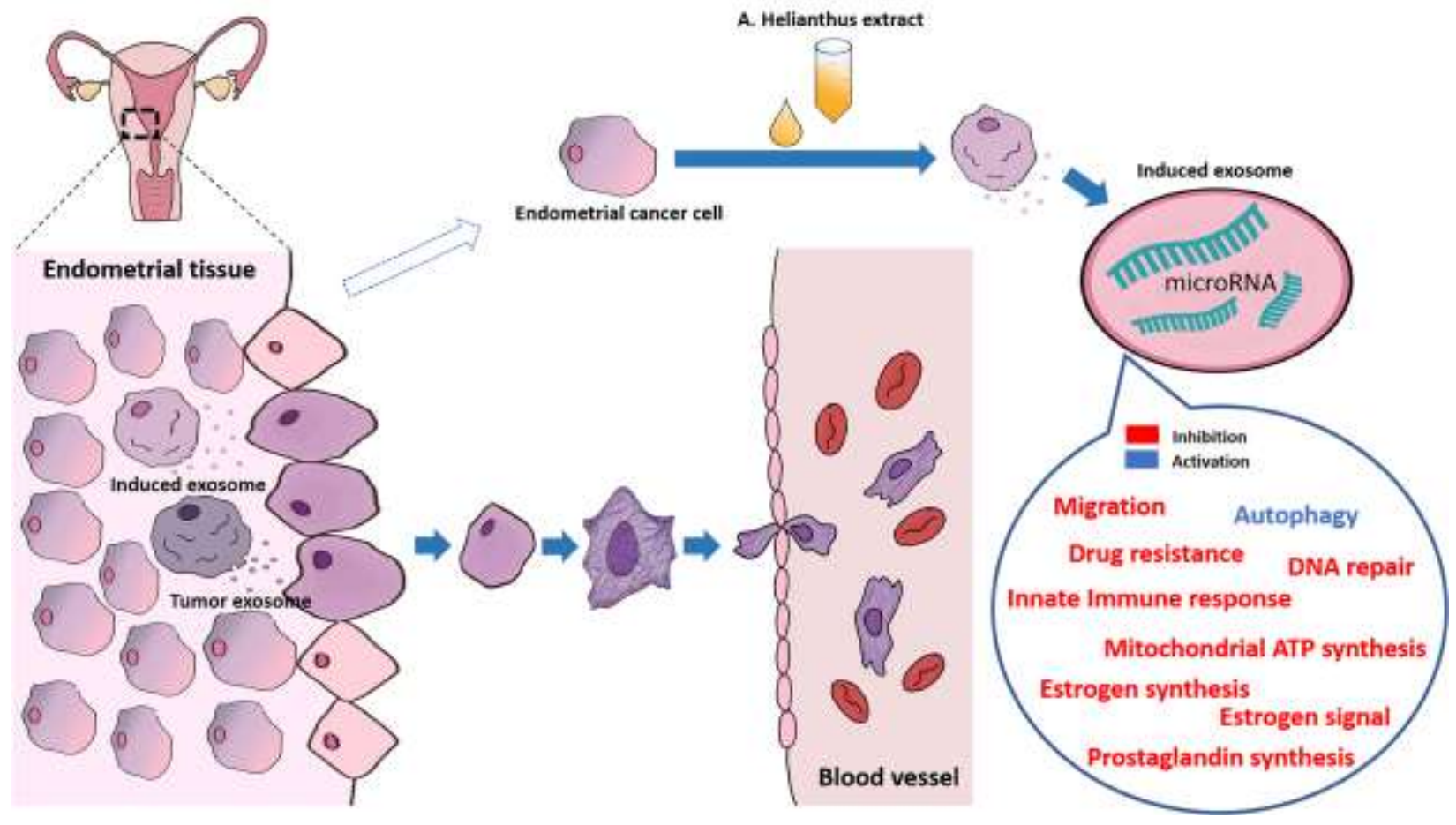

Figure 1. Schematic working flow for the research

Exposed to the A. helianthus extract, the endometrial cancer cells produced specific exosomes containing microRNAs involved in significant bioactivities. 

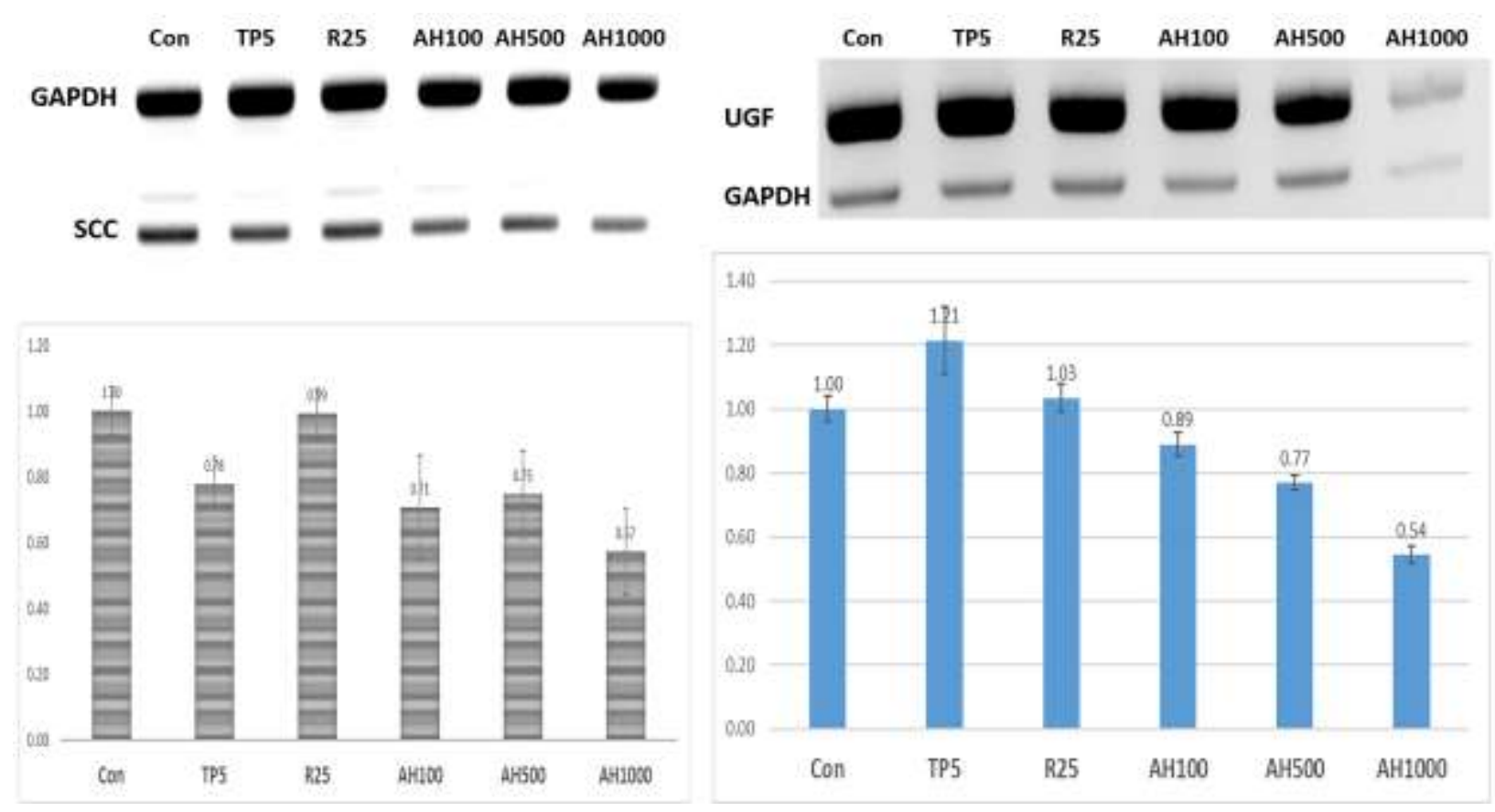

Figure 2. Expression levels of endometrial cancer cell markers under bioactive substances.

Exposed to the bioactive substances including tocopherol- $\alpha, 5 \mu \mathrm{g} / \mathrm{mL}$ (TP5), rutin $25 \mu \mathrm{g} / \mathrm{mL}$ (R25) and $A$. helianthus extract (AH) 100, 500, $1000 \mu \mathrm{g} / \mathrm{mL}$, the markers of the endometrial cancer cells were downregulated. squamous cell carcinoma (SCC), urinary gonadotropin fragment (UGF). $(P<0.05)$ 

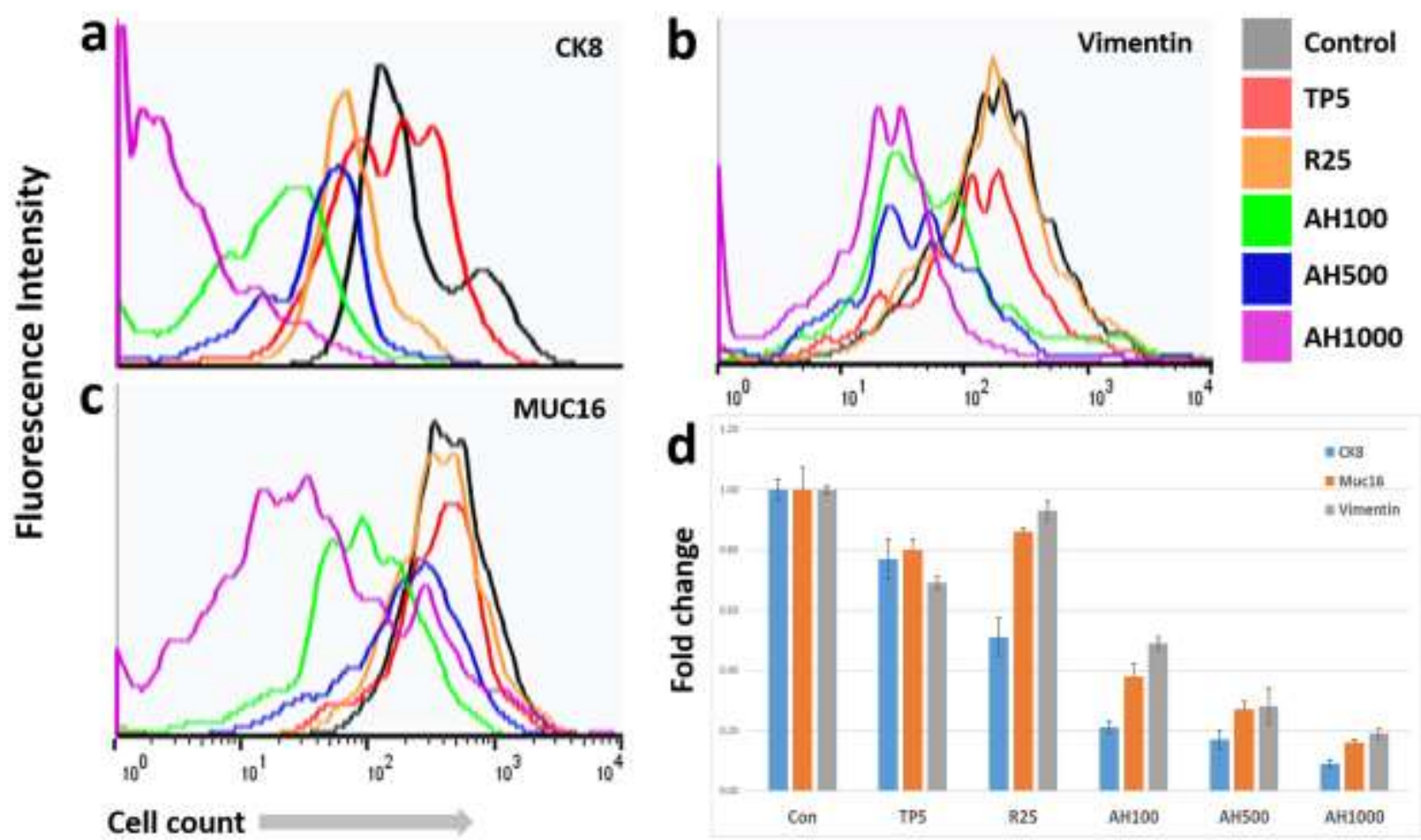

Figure 3. Expression of cancerous markers in endometrial cancer cells under bioactive substances

The $\mathrm{CK}^{+}$, Muc16 ${ }^{+}$and Vimentin ${ }^{+}$cells were counted by a flowcytometer. Tocopherol- $\alpha, 5 \mu \mathrm{g} / \mathrm{mL}$ (TP5),

Rutin $25 \mu \mathrm{g} / \mathrm{mL}$ (R25) and A. helianthus extract (AH) 100, 500, $1000 \mu \mathrm{g} / \mathrm{mL} .(P<0.05)$ 
a

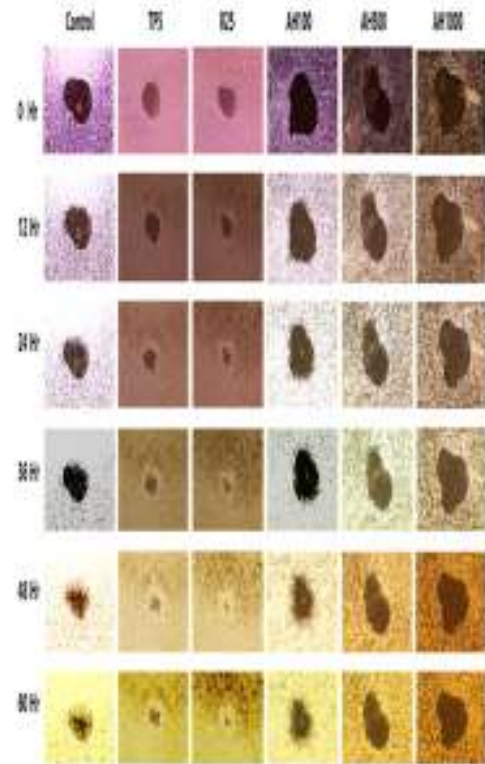

b

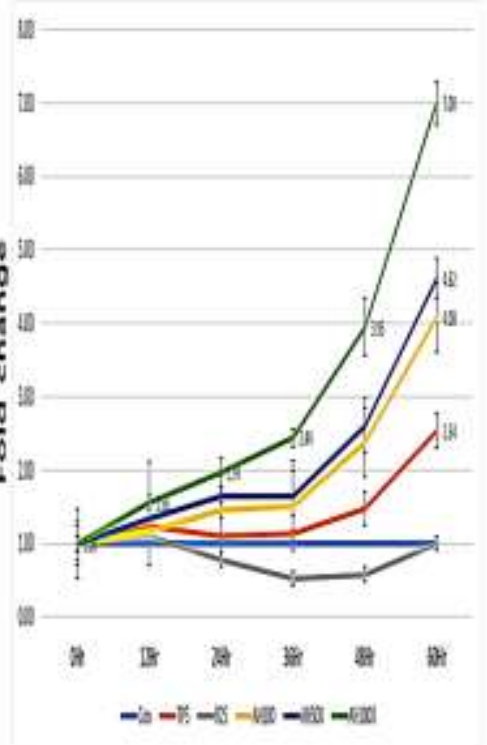

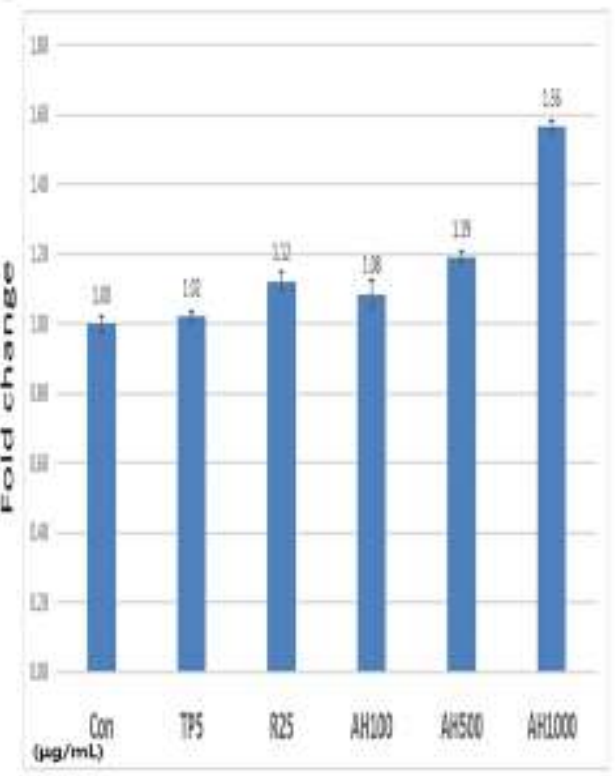

Figure 4. Metastatic and invasive inhibition of endometrial cancer cells by bioactive substances

a. The areas without migrated cells were measured with Nikon software and the measured values indicated the relative fold changes. $\mathrm{b}$. The bar graphs displayed non-invasive cells under the substances, tocopherol$\alpha, 5 \mu \mathrm{g} / \mathrm{mL}$ (TP5), rutin $25 \mu \mathrm{g} / \mathrm{mL}$ (R25) and A. helianthus extract (AH) 100, 500, $1000 \mu \mathrm{g} / \mathrm{mL} .(P<0.05)$
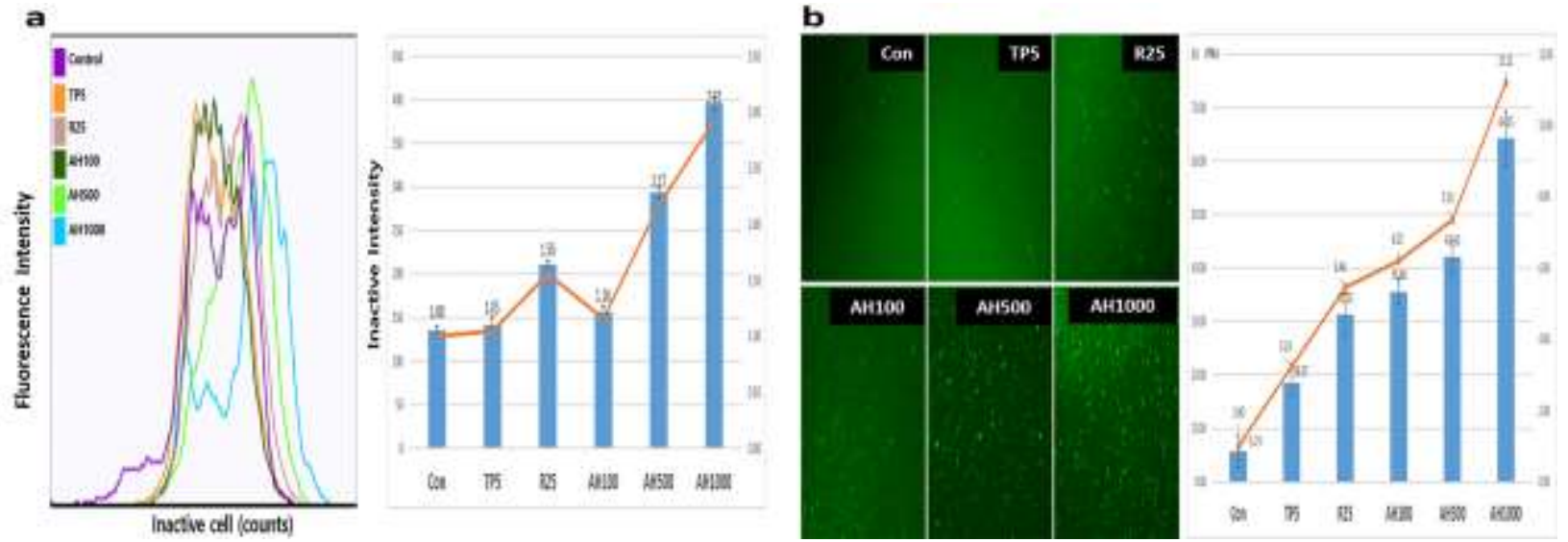
Figure 5. Effects of bioactive substances for mitochondrial membrane potential and senescence on endometrial cancer cells

a. The specific fluorescence was stained in the inactive cells. Tocopherol- $\alpha, 5 \mu \mathrm{g} / \mathrm{mL}$ (TP5), Rutin $25 \mu \mathrm{g} / \mathrm{mL}$ (R25) and A. helianthus extract (AH) 100, 500, $1000 \mu \mathrm{g} / \mathrm{mL}$. b. The labeled cells indicated senescence cells. Tocopherol- $\alpha, 5 \mu \mathrm{g} / \mathrm{mL}$ (TP5), Rutin $25 \mu \mathrm{g} / \mathrm{mL}$ (R25) and A. helianthus extract (AH) 100, 500, $1000 \mu \mathrm{g} / \mathrm{mL}$. $(P<0.05)$

a

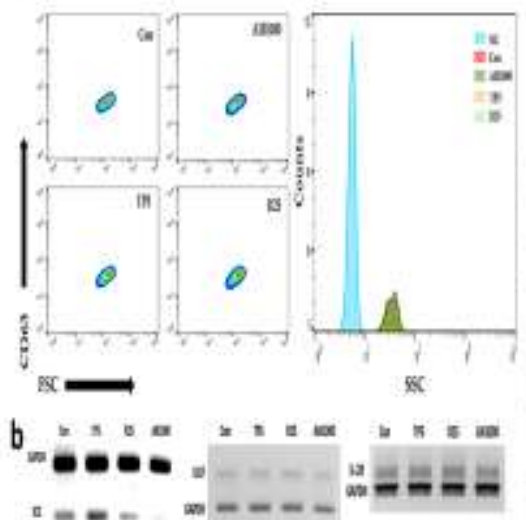

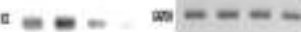

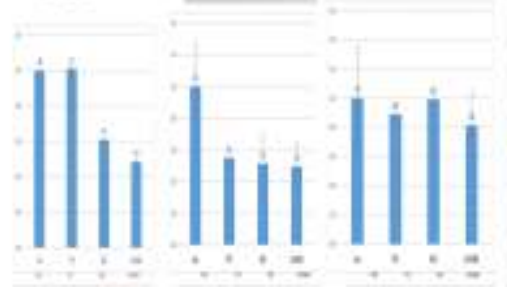

C
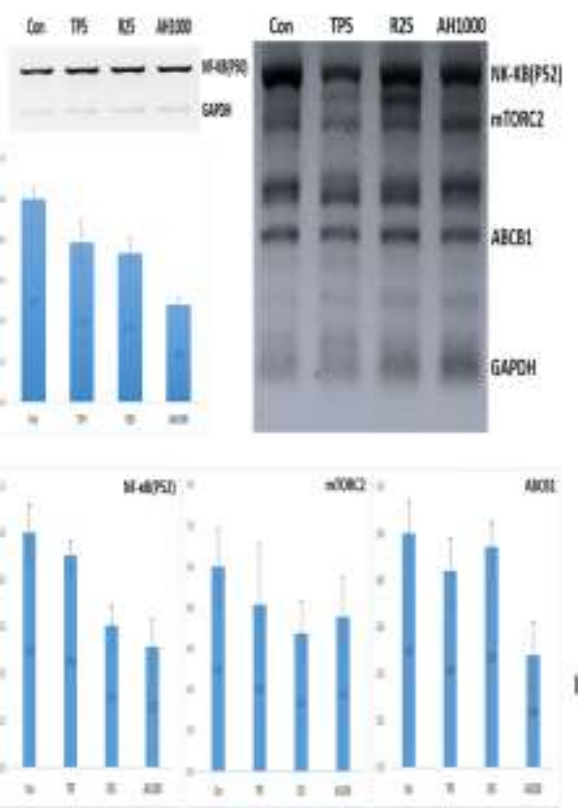

d
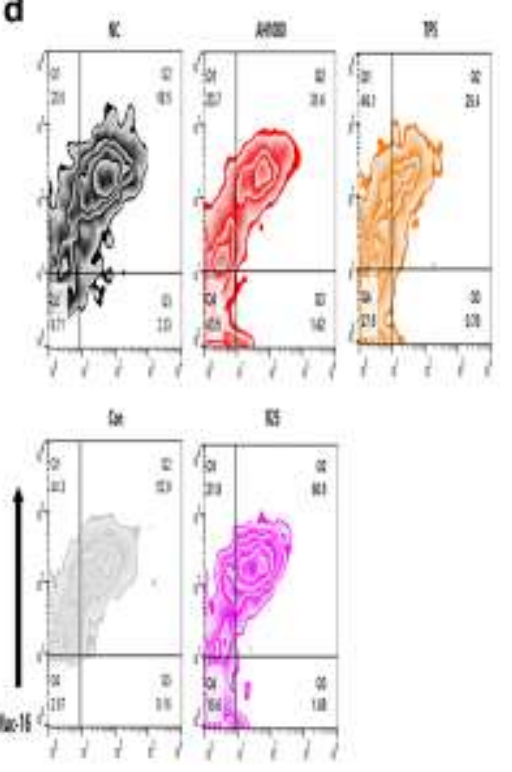

Vheth

Figure6. Expression of cancerous markers in endometrial cancer cells under the induced exosomes

a. The histograms indicated the induced exosomes from endometrial cancer cells. b. The graphs mean expression of the markers in endometrial cancer cells under exosomes. c. Expression levels of drug resistance and autophagy associated genes under the induced exosomes. $\mathrm{d}$. The cell counts for Muc16 and 
vimentin ${ }^{+}$cells in endometrial cancer cells under exosomes Tocopherol- $\alpha, 5 \mu \mathrm{g} / \mathrm{mL}$ (TP5), Rutin $25 \mu \mathrm{g} / \mathrm{mL}$ (R25) and A. helianthus extract (AH) 100, 500, $1000 \mu \mathrm{g} / \mathrm{mL} .(P<0.05)$
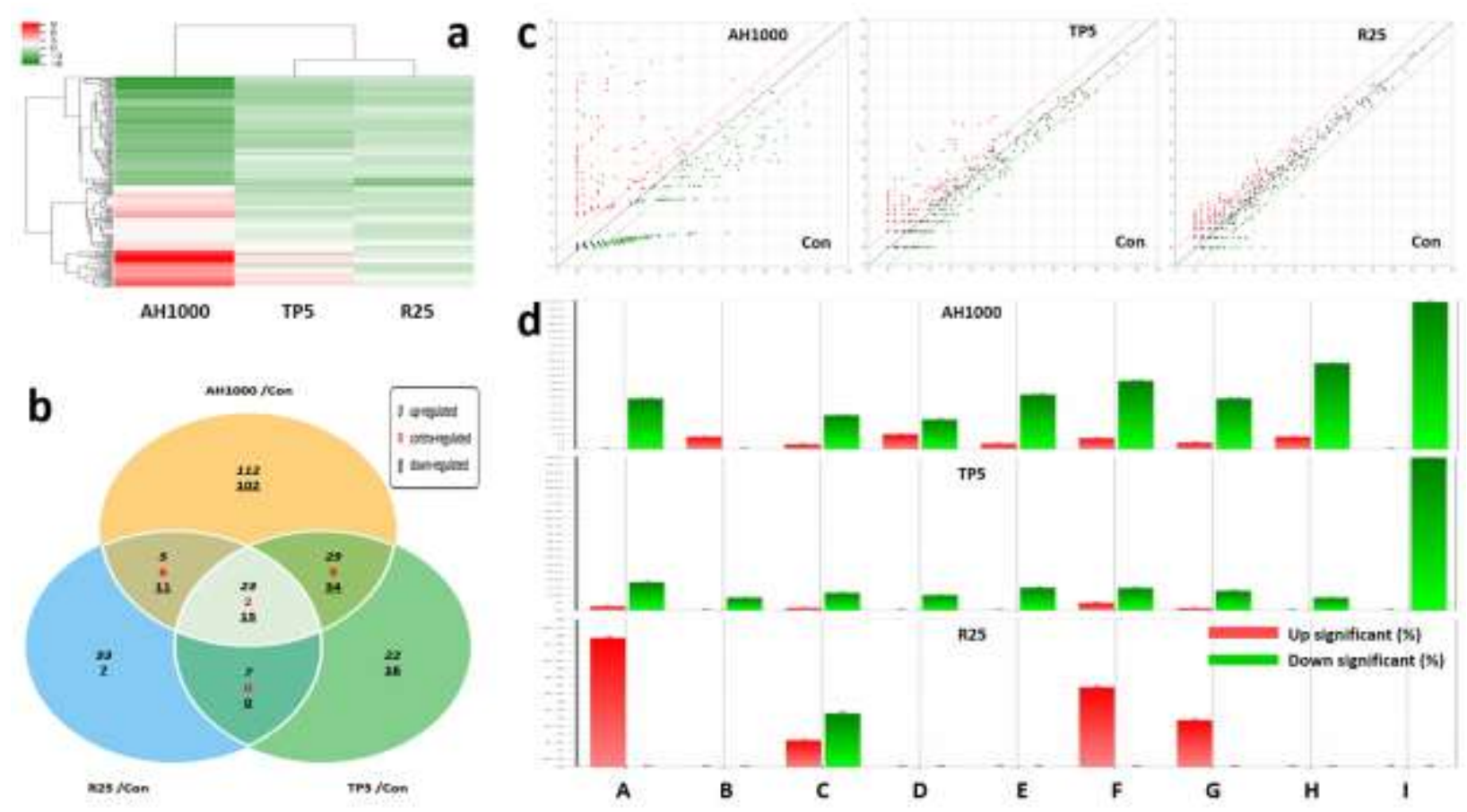

Figure 7. Profiling of miRNAs in the induced exosomes from endometrial cancer cells

a. The heat map for microRNA in exosomes induced by three substances. b. The van diagram for microRNAs in endometrial cancer cells under the three substances. c. The scattering plots between the control and bioactive substances. $d$. The microRNAs were involved in several categories (A: positive regulation of autophagy,B: drug transmembrane transport,C: positive regulation of cell migra tion involved in sprouting angiogenesis,D: estrogen biosynthetic process, E: positive regulation of prostag landin biosynthetic process,F: mitochondrial ATP synthesis coupled proton transport,G: positive regulati on of DNA repair regulation of innate immune response, $\mathrm{H}$ : negative regulation of intracellular estrogen 
receptor signaling pathway,I: positive regulation of DNA repair). f. The van diagram for microRNAs in endometrial cancer cells under the three substances. Tocopherol- $\alpha, 5 \mu \mathrm{g} / \mathrm{mL}$ (TP5), Rutin $25 \mu \mathrm{g} / \mathrm{mL}$ (R25) and A. helianthus extract (AH) 100, 500, $1000 \mu \mathrm{g} / \mathrm{mL} .(P<0.05)$
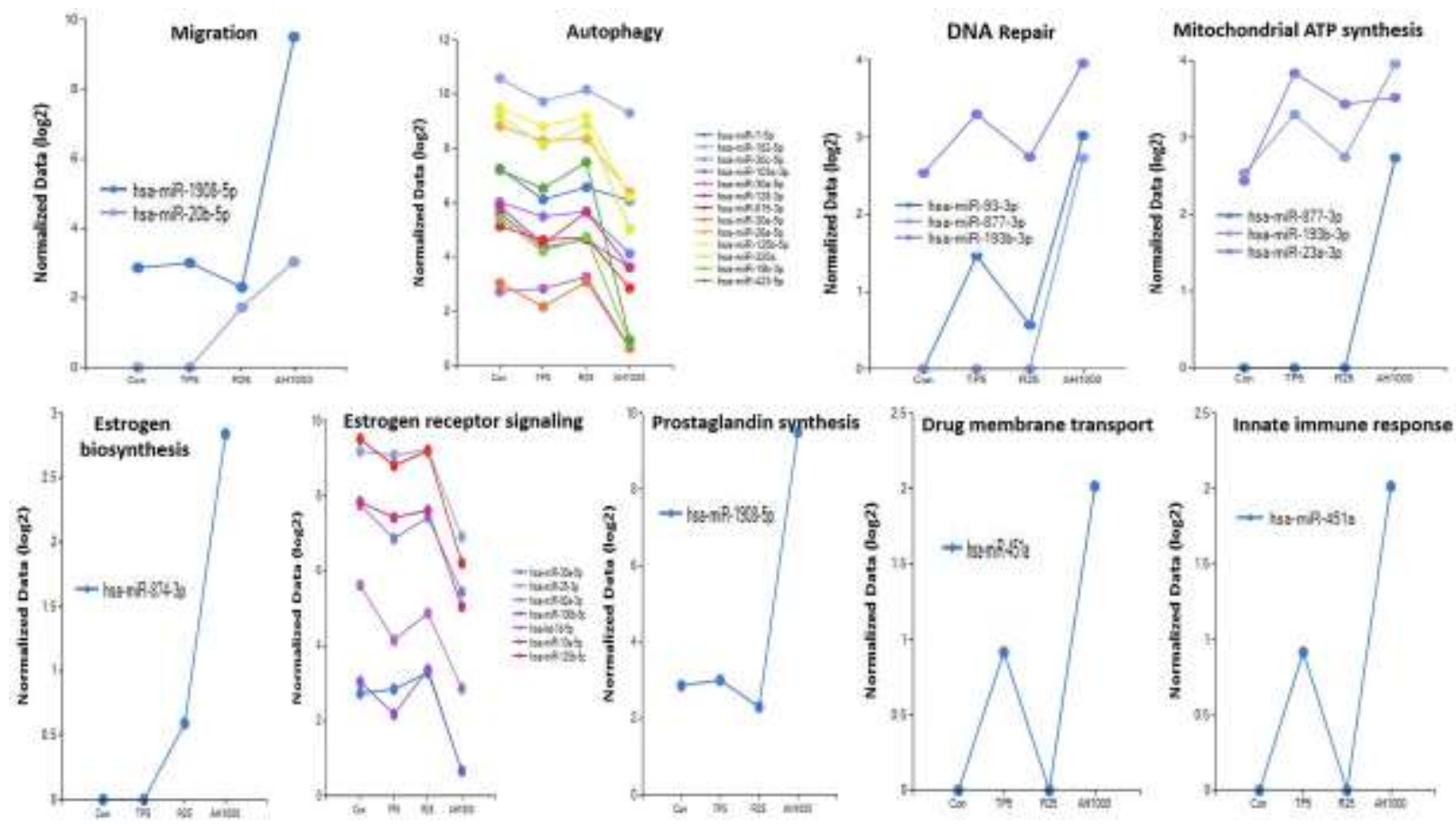

Figure 8. Biological categories and symbols of bioactive microRNAs in the exosomes

The plots displayed the biological classification of significant microRNAs in the induced. Tocopherol- $\alpha, 5$ $\mu \mathrm{g} / \mathrm{mL}$ (TP5), Rutin $25 \mu \mathrm{g} / \mathrm{mL}$ (R25) and A. helianthus extract (AH) 100, 500, $1000 \mu \mathrm{g} / \mathrm{mL}$. (2 times $\leq$ fold changes and 0.5 times $\geq$ fold changes $)(P<0.05)$ 


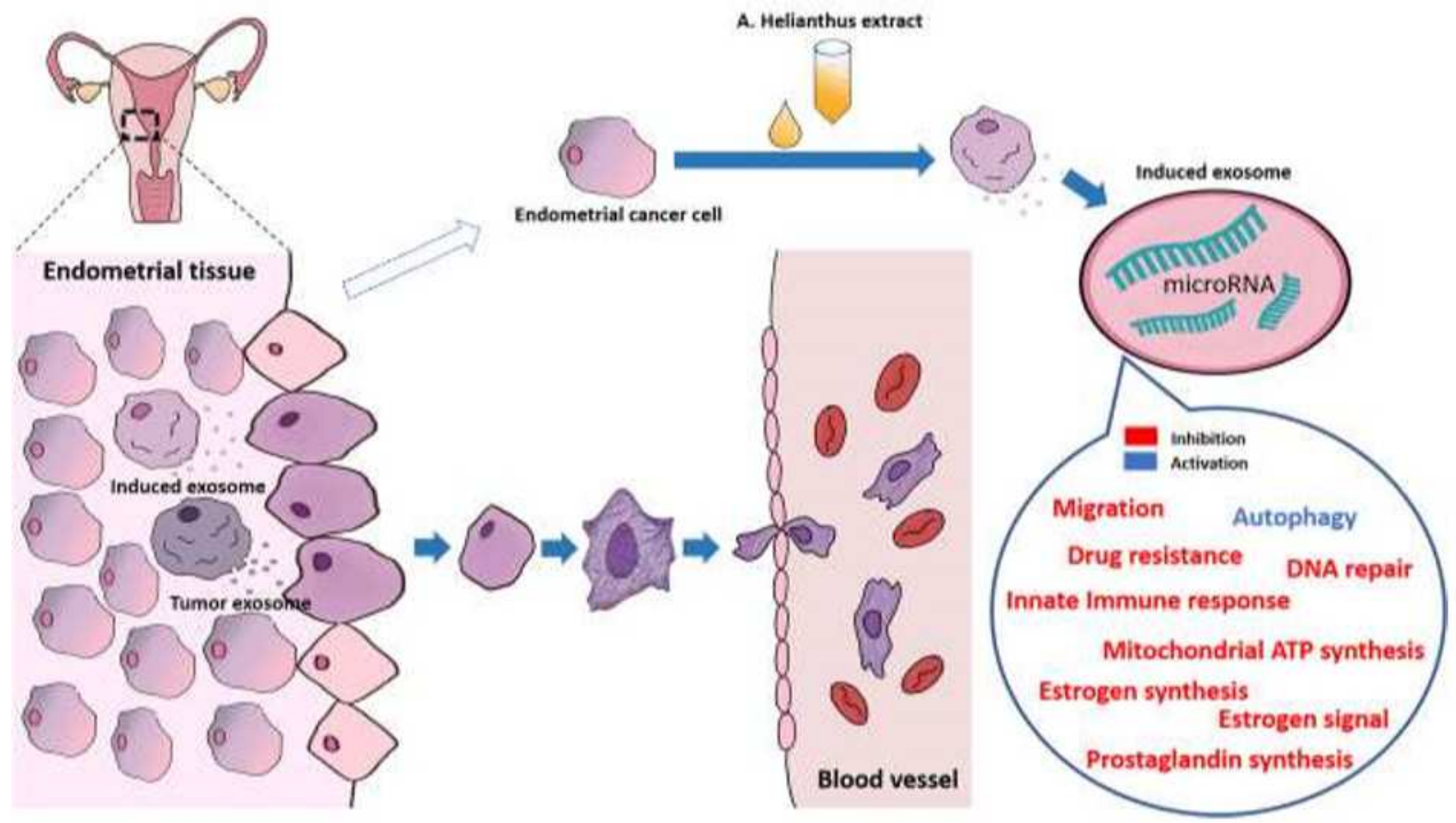

\section{Figure 1}

Schematic working flow for the research Exposed to the A. helianthus extract, the endometrial cancer cells produced specific exosomes containing microRNAs involved in significant bioactivities.
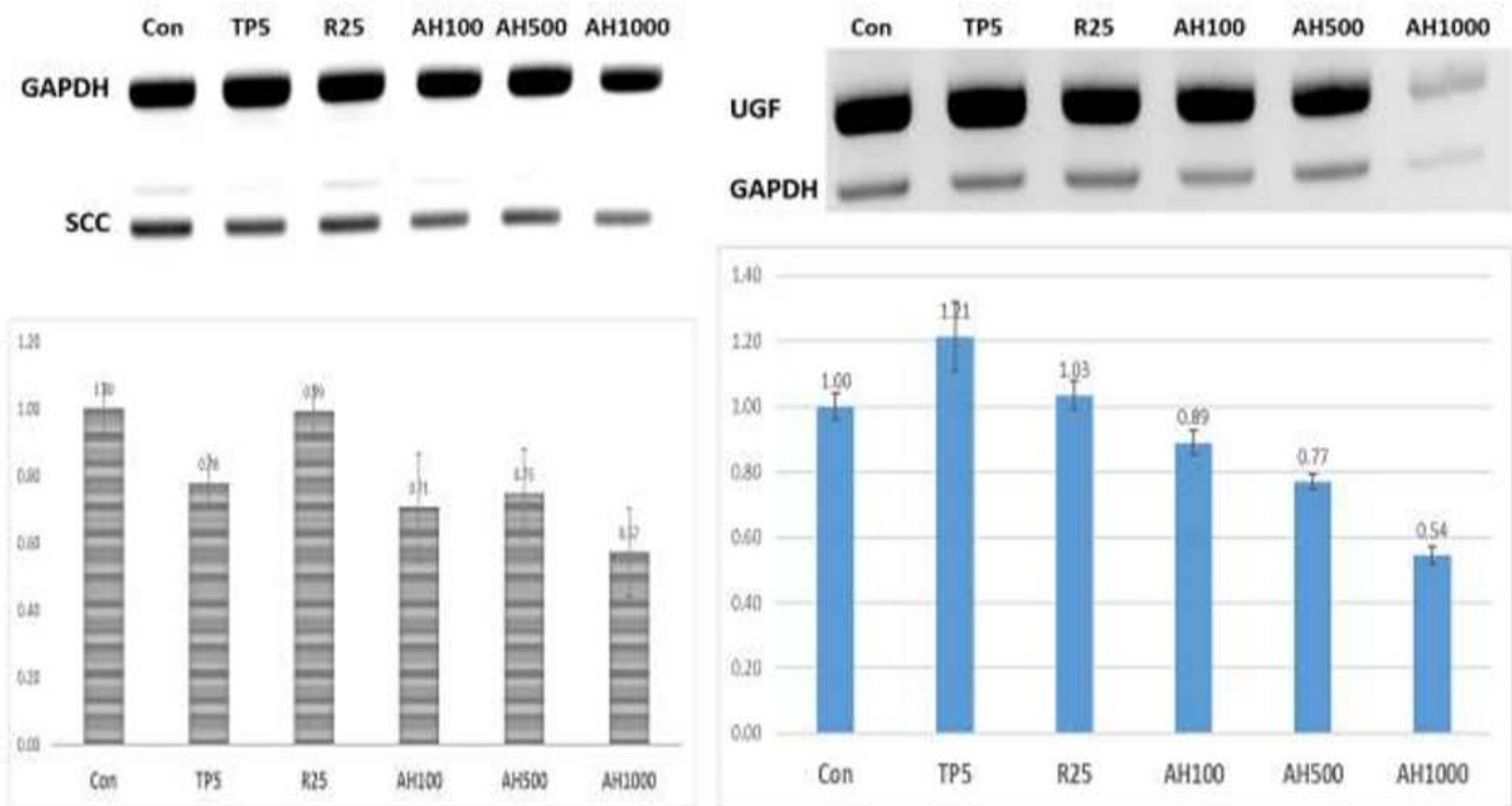
Figure 2

Expression levels of endometrial cancer cell markers under bioactive substances. Exposed to the bioactive substances including tocopherol-a, $5 \mu \mathrm{g} / \mathrm{mL}$ (TP5), rutin $25 \mu \mathrm{g} / \mathrm{mL}$ (R25) and A. helianthus extract $(A H) 100,500,1000 \mu \mathrm{g} / \mathrm{mL}$, the markers of the endometrial cancer cells were down regulated. squamous cell carcinoma (SCC), urinary gonadotropin fragment (UGF). $(P<0.05)$

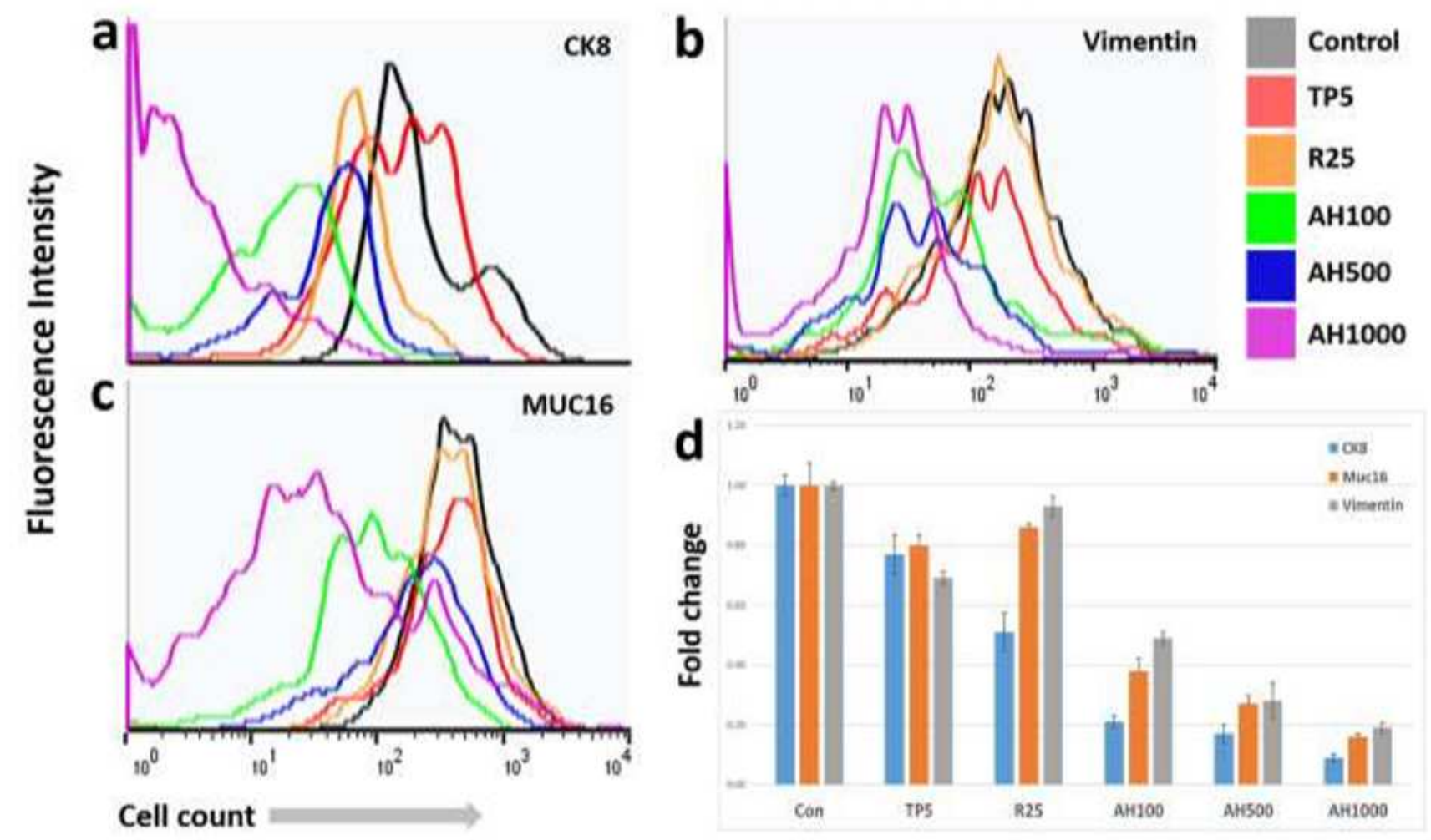

Figure 3

Expression of cancerous markers in endometrial cancer cells under bioactive substances The CK8+, Muc16+ and Vimentin + cells were counted by a flowcytometer. Tocopherol-a, $5 \mu \mathrm{g} / \mathrm{mL}$ (TP5), Rutin $25 \mu$ $\mathrm{g} / \mathrm{mL}(\mathrm{R} 25)$ and A. helianthus extract $(\mathrm{AH}) 100,500,1000 \mu \mathrm{g} / \mathrm{mL} .(P<0.05)$ 


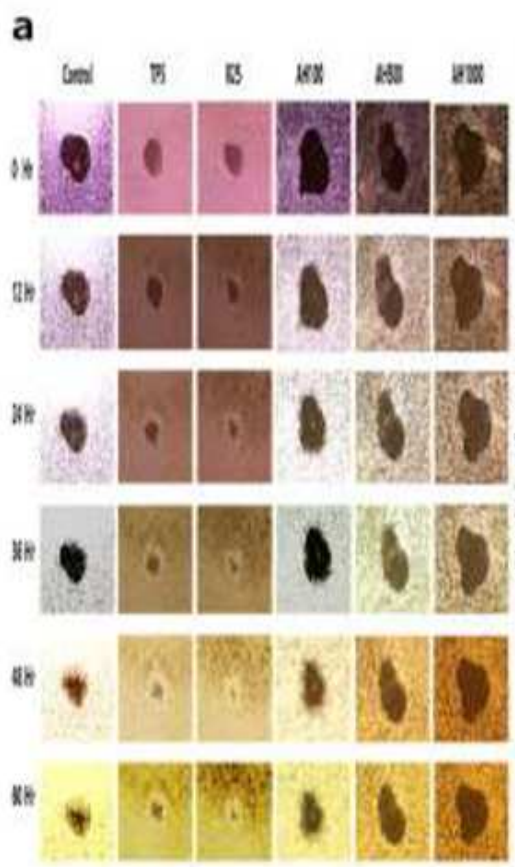

b
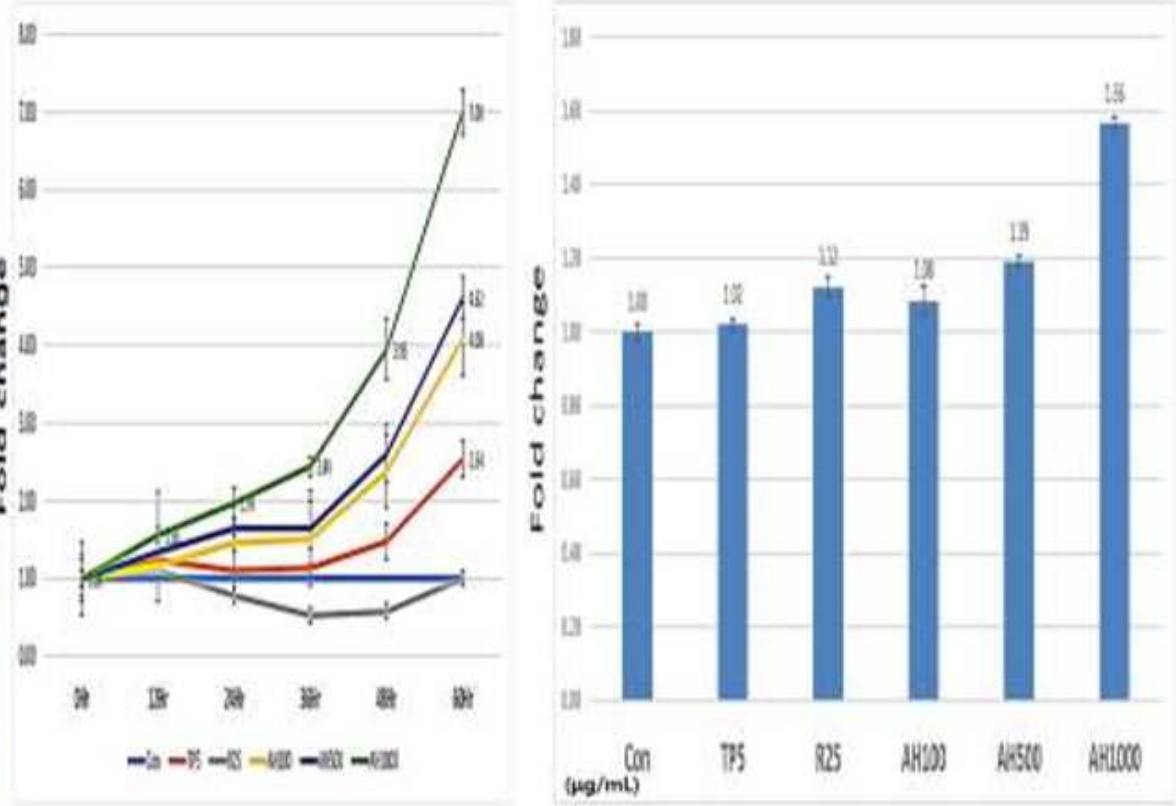

\section{Figure 4}

Metastatic and invasive inhibition of endometrial cancer cells by bioactive substances a. The areas without migrated cells were measured with Nikon software and the measured values indicated the relative fold changes. $b$. The bar graphs displayed non-invasive cells under the substances, tocopherol $a$, $5 \mu \mathrm{g} / \mathrm{mL}$ (TP5), rutin $25 \mu \mathrm{g} / \mathrm{mL}$ (R25) and A. helianthus extract (AH) 100, 500, $1000 \mu \mathrm{g} / \mathrm{mL}$. $(P<0.05)$
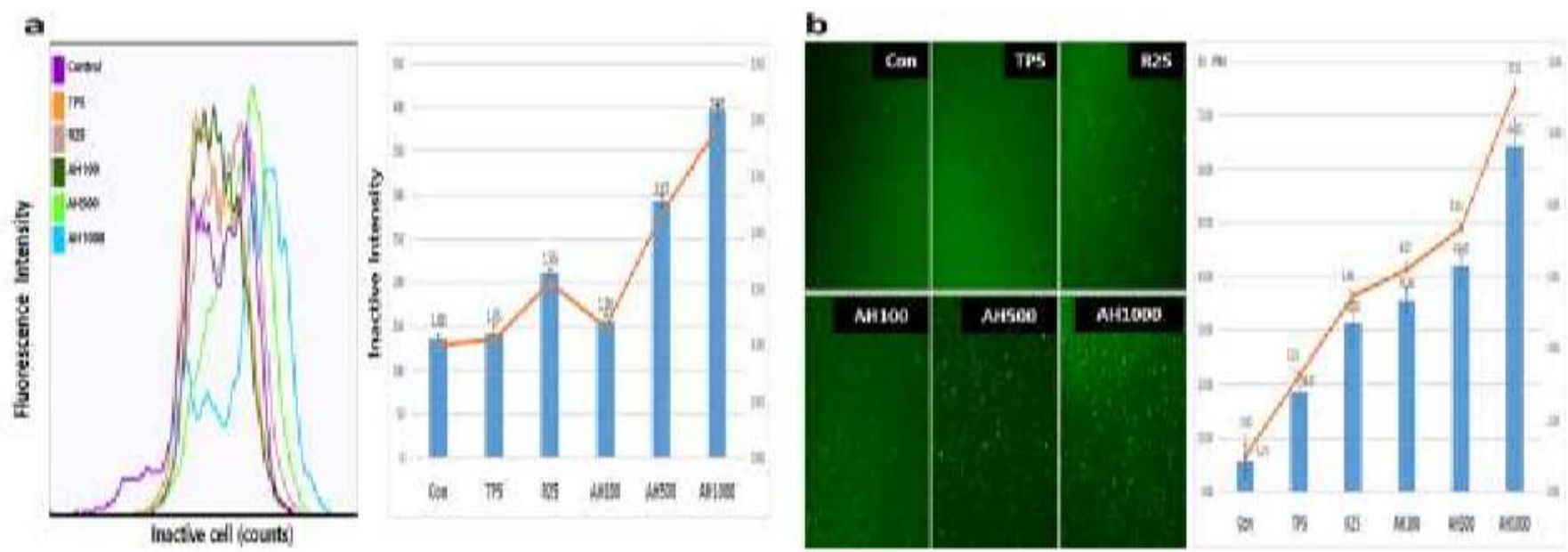

\section{Figure 5}

Effects of bioactive substances for mitochondrial membrane potential and senescence on endometrial cancer cells a. The specific fluorescence was stained in the inactive cells. Tocopherol-a, $5 \mu \mathrm{g} / \mathrm{mL}$ (TP5), 
Rutin $25 \mu \mathrm{g} / \mathrm{mL}$ (R25) and A. helianthus extract (AH) 100, 500, $1000 \mu \mathrm{g} / \mathrm{mL}$. b. The labeled cells indicated senescence cells. Tocopherol-a, $5 \mu \mathrm{g} / \mathrm{mL}$ (TP5), Rutin $25 \mu \mathrm{g} / \mathrm{mL}$ (R25) and A. helianthus extract $(A H) 100,500,1000 \mu \mathrm{g} / \mathrm{mL} .(P<0.05)$
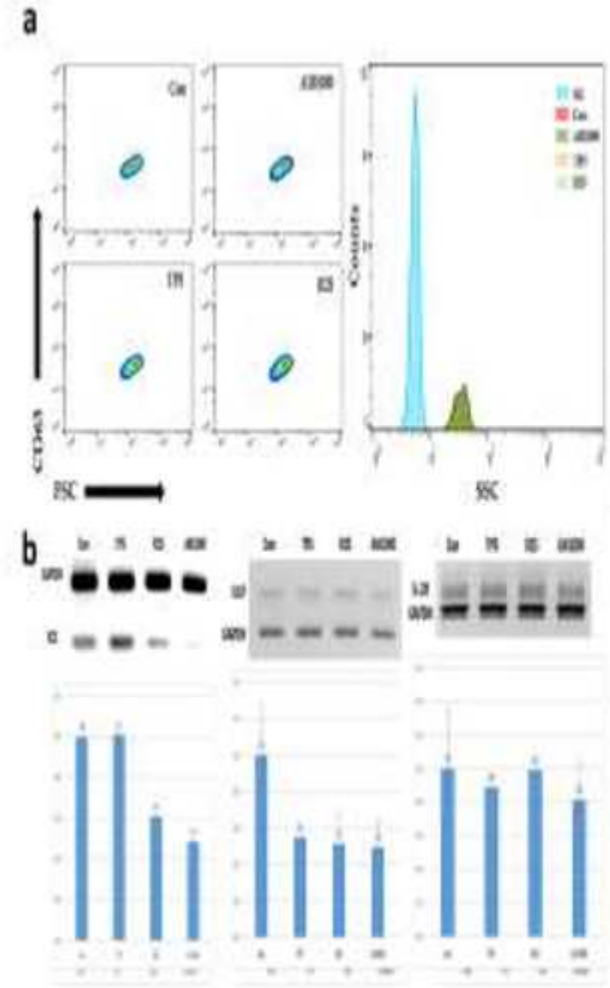

c
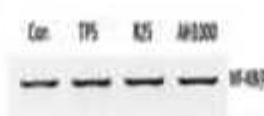

ars
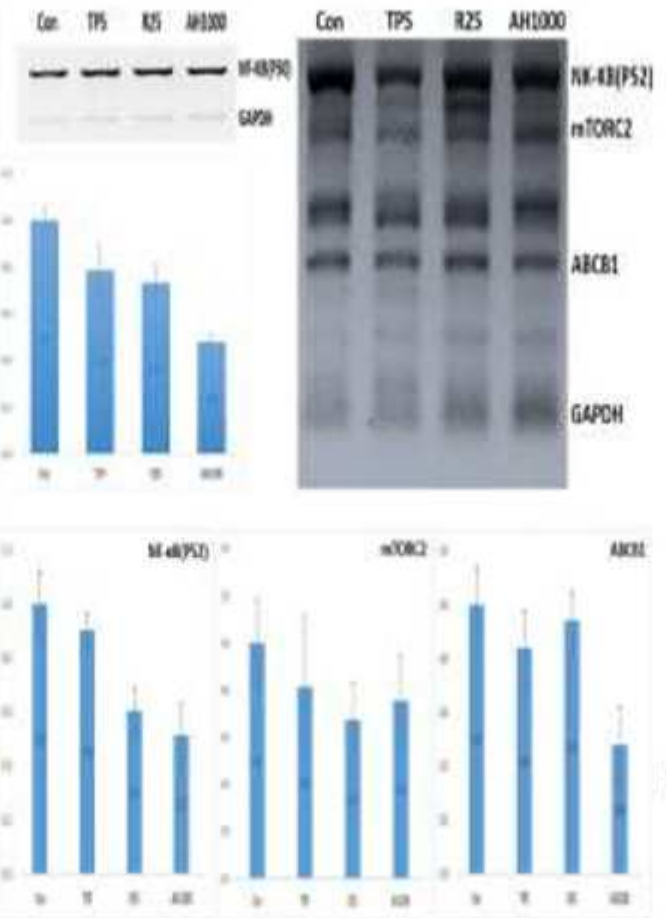

d

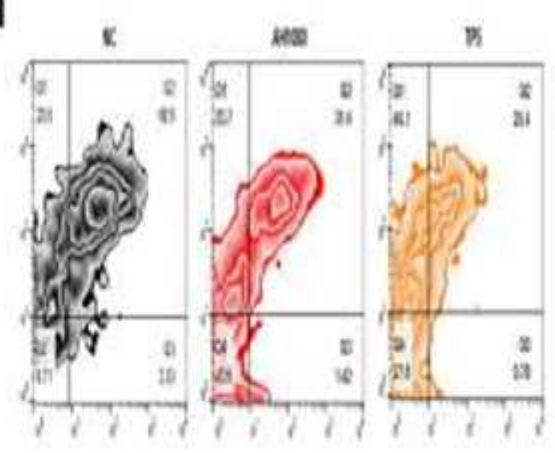

s

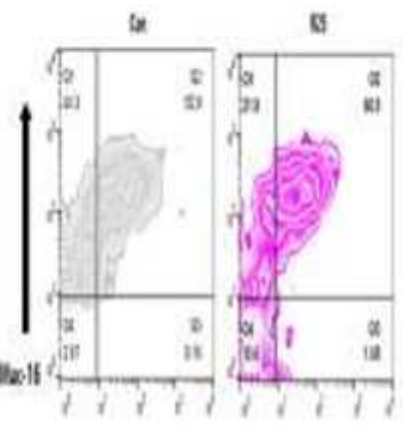

Figure 6

Expression of cancerous markers in endometrial cancer cells under the induced exosomes a. The histograms indicated the induced exosomes from endometrial cancer cells. b. The graphs mean expression of the markers in endometrial cancer cells under exosomes. c. Expression levels of drug resistance and autophagy associated genes under the induced exosomes. $d$. The cell counts for Muc16+ and vimentin + cells in endometrial cancer cells under exosomes Tocopherol-a, $5 \mu \mathrm{g} / \mathrm{mL}$ (TP5), Rutin $25 \mu$ $\mathrm{g} / \mathrm{mL}(\mathrm{R} 25)$ and A. helianthus extract $(\mathrm{AH}) 100,500,1000 \mu \mathrm{g} / \mathrm{mL} .(P<0.05)$ 

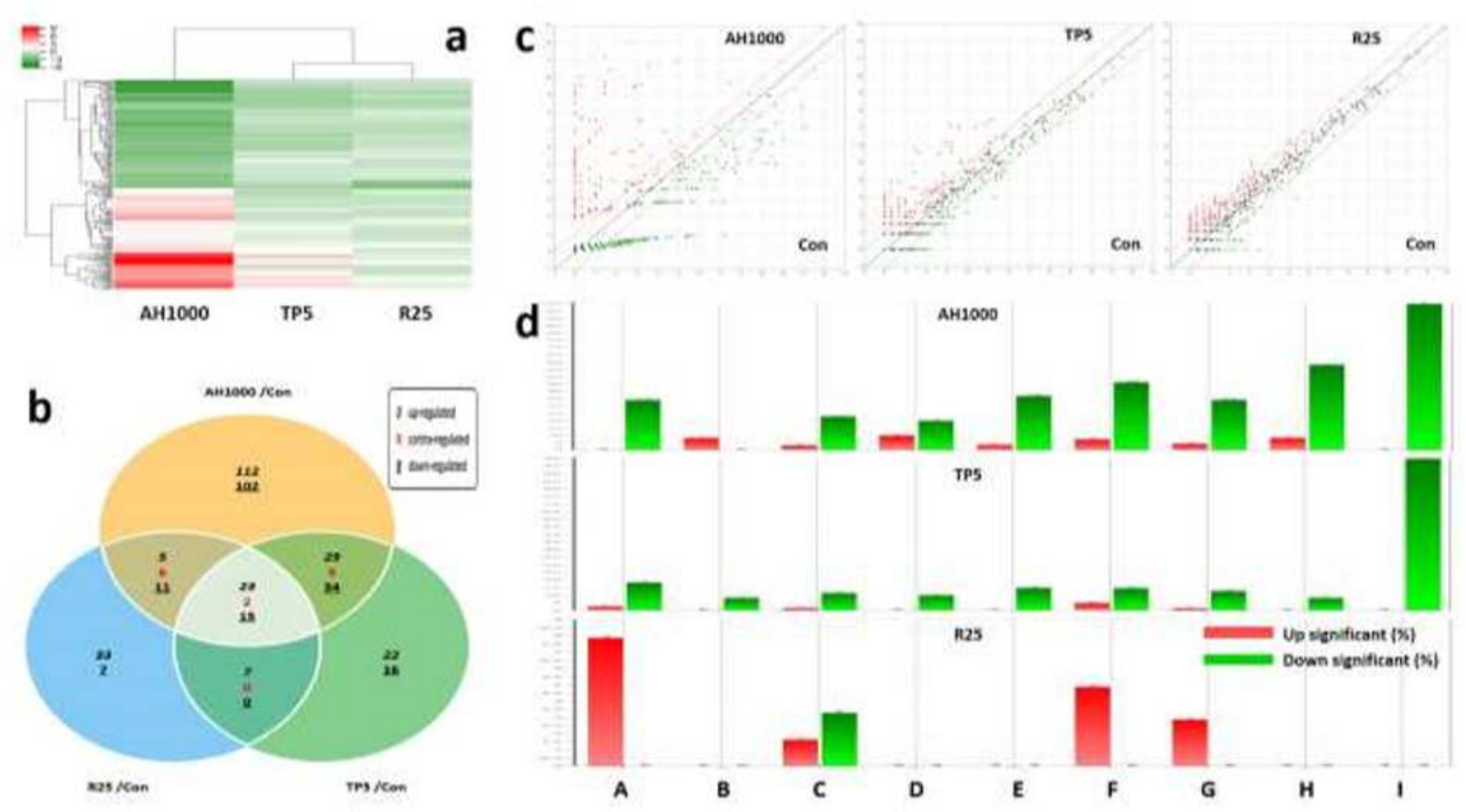

\section{Figure 7}

Profiling of miRNAs in the induced exosomes from endometrial cancer cells a. The heat map for microRNA in exosomes induced by three substances. b. The van diagram for microRNAs in endometrial cancer cells under the three substances. c. The scattering plots between the control and bioactive substances. $d$. The microRNAs were involved in several categories (A: positive regulation of autophagy,B: drug transmembrane transport,C: positive regulation of cell migra tion involved in sprouting angiogenesis,D: estrogen biosynthetic process,E: positive regulation of prostag landin biosynthetic process,F: mitochondrial ATP synthesis coupled proton transport,G: positive regulati on of DNA repair regulation of innate immune response,H: negative regulation of intracellular estrogen receptor signaling pathway,l: positive regulation of DNA repair). $f$. The van diagram for microRNAs in endometrial cancer cells under the three substances. Tocopherol-a, $5 \mu \mathrm{g} / \mathrm{mL}$ (TP5), Rutin $25 \mu \mathrm{g} / \mathrm{mL}$ (R25) and A. helianthus extract (AH) 100, 500, $1000 \mu \mathrm{g} / \mathrm{mL} .(P<0.05)$ 

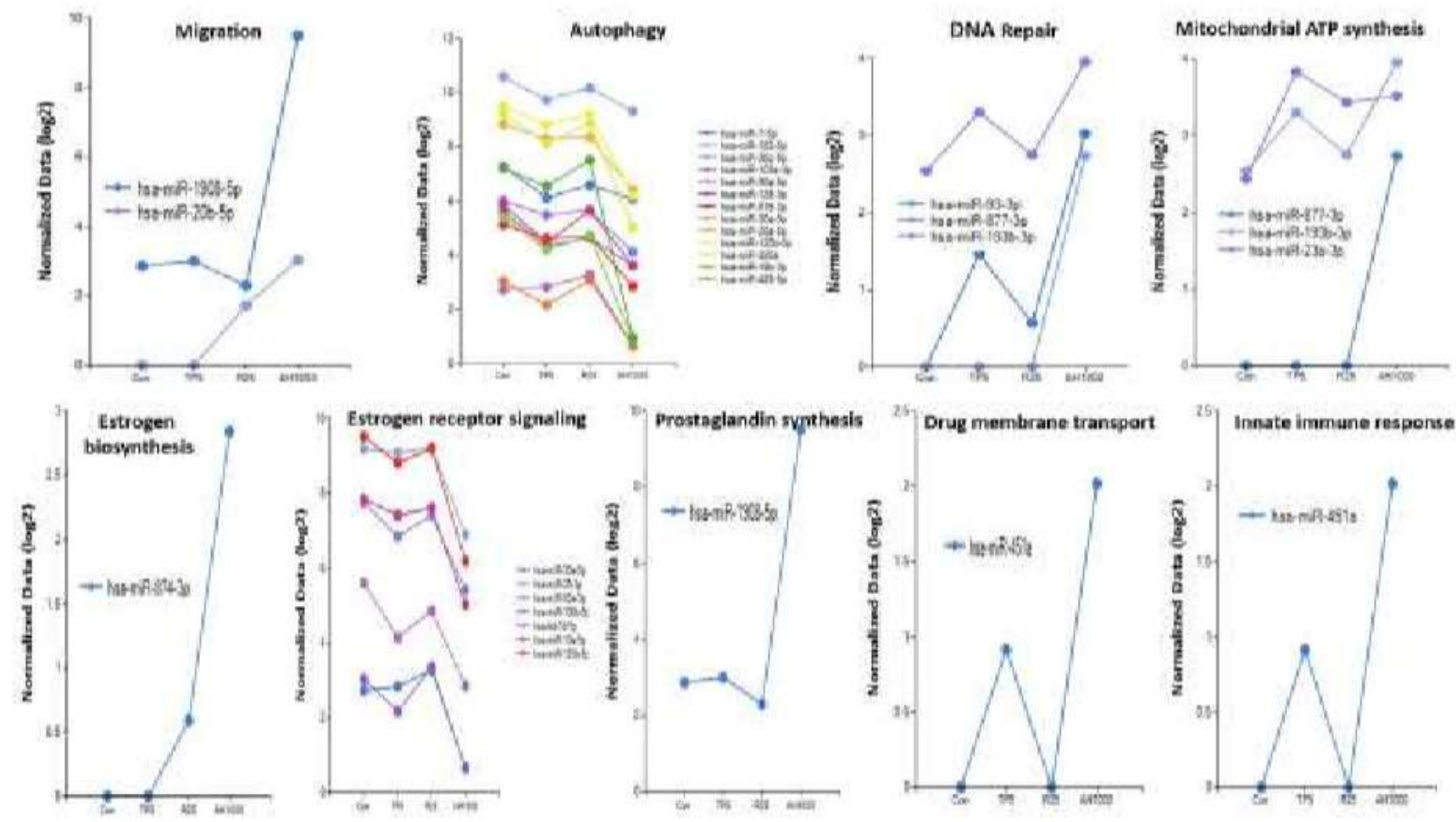

\section{Figure 8}

Biological categories and symbols of bioactive microRNAs in the exosomes The plots displayed the biological classification of significant microRNAs in the induced. Tocopherol-a, $5 \mu \mathrm{g} / \mathrm{mL}$ (TP5), Rutin $25 \mu$ $\mathrm{g} / \mathrm{mL}$ (R25) and A. helianthus extract (AH) 100, 500, $1000 \mu \mathrm{g} / \mathrm{mL}$. (2 times $\leq$ fold changes and 0.5 times $\geq$ fold changes $)(P<0.05)$

\section{Supplementary Files}

This is a list of supplementary files associated with this preprint. Click to download.

- fullgels.pdf 